\title{
A Seismotectonic Analysis of the Anza Seismic Gap, San Jacinto Fault Zone, Southern California
}

\author{
Chris O. Sanders and Hiroo Kanamori
}

Seismological Laboratory, California Institute of Technology

\begin{abstract}
Small earthquakè epicenters near the Anza seismic gap define a $20-\mathrm{km}$ quiescent segment of fault bounded to the northwest and southeast by areas of relatively high seismicity. Recent moderate earthquakes on and near the San Jacinto fault in the gap and their relatively depressed aftershock activity indicate that the fault is seismogenic and highly stressed but locked by some mechanism. The locked nature of the fault may be due to relatively high compressive stress normal to the fault resulting from the convergent geometries of the local, active, discontinuous faults and the oblique orientation of the regional maximum compressive stress. Strain is not being relieved by aseismic fault creep. A swarm of small earthquakes in the crustal block $13 \mathrm{~km}$ southwest of the Anza gap beneath the Cahuilla Valley recently released stress in an area which was previously highly active before the 1918 $(M 6.8)$ and $1937\left(M_{L} 6.0\right)$ earthquakes. The occurrence of these periods of increased seismicity near Cahuilla in the years immediately before the nearby (closer than $35 \mathrm{~km}$ ) large earthquakes and the recent swarm suggest that the ground beneath Cahuilla may be acting as a stress meter signaling the presence of high stresses before large local earthquakes. The length of the quiescent fault segment suggests potential for about an $M 6.5$ earthquake if the entire segment ruptures at once.
\end{abstract}

\section{INTRODUCTION}

Historically, the San Jacinto fault zone has been the most seismically active fault system in southern California. Since 1890 at least six and perhaps as many as 10 earthquakes greater than magnitude 6 were associated with faults in this zone. The spatial distribution and sizes of these large earthquakes indicate that two short sections of the San Jacinto fault are relatively deficient in seismic slip and can be considered seismic gaps [Thatcher et al., 1975]. One of these, the "Anza to Coyote Mountain seismic slip gap" was originally defined as the $40-\mathrm{km}$ stretch of the fault zone between the 1918 San Jacinto and 1968 Borrego Mountain earthquake ruptures (Figures 1 and 2)[Thatcher et al., 1975] The Anza seismic gap as presented in this discussion is defined as the $20-\mathrm{km}$ aseismic section of the San Jacinto fault centered near the town of Anza and is included within the larger seismic slip gap (Figure 3)[Sanders et al., 1981]. The length of the Anza seismic gap implies potential for a magnitude 6.5 event, similar to historic large earthquakes in other parts of the fault zone.

This study was undertaken in order to understand better the relation between the geology and seismicity in the area of the Anza seismic gap and to determine the nature of seismic stress release near the gap. The data for this analysis included the historical seismicity, recent seismicity and source mechanisms, local three-dimensional fault geometries, tectonic and geologic setting, and local and regional strain measurements. The results indicate that the quiescent section of the Anza seismic gap is seismogenic and highly stressed but locked by some mechanism [Sanders and Kanamori, 1982]. The local structural geology and regional stress field suggest that relatively high compression normal to the fault plane may be the cause of the locking. In addition, an earthquake swarm area close to the gap may

Copyright 1984 by the American Geophysical Union.

Paper number 4B0173.

0148-0227/84/004B-0173\$05.00 be acting as a stress meter signaling high stresses in the region.

\section{Historical EARThQuakes in the SAN Jacinto FAult ZoNe}

The history of large earthquakes associated with the San Jacinto fault zone is important for identifying the areas of greatest and least historic stress release and for indicating the maximum size of earthquakes associated with the faults in this zone. All large earthquakes which have occurred in this fault zone since 1890 are known. No earlier large events are reported [Toppozada et al., 1981], but the early historical record may be incomplete.

At least two and perhaps four historical events have been associated with the San Jacinto fault zone northwest of Anza since 1890 (Figure 2). The two earthquakes definitely associated with this zone occurred on December 25, 1899 ( $M$ 7; this magnitude is inferred by comparison of the intensities of this and the 1918 earthquake), and April 21, 1918 (M 6.8 [Richter, 1958]). An event on July 22, 1923 (M 6 [Richter, 1958]), is very likely associated with the San Jacinto fault. Another earthquake on July 22, $1899\left(M_{I}\right.$ 6.5; $M_{I}$ signifies magnitude determined from intensity data [Toppozada et al., 1981]), was strongly felt in the Cajon Pass region, near the intersection of the San Jacinto and San Andreas faults but could be associated with either of these faults or several others in the area. The magnitudes of the 1918 and 1923 earthquakes are approximate Richter magnitudes obtained from a comparison of the earthquake seismograms recorded at a few regional seismograph stations with the seismograms of modern earthquakes recorded on the same instruments at those stations and also on WoodAnderson instruments (C. Richter, personal communication, December 1982).

The July 22,1923 , earthquake is located only approximately based on damage reports but is most likely associated with the San Jacinto fault in the San Bernardino Valley (Figure 1). The $P$ and $S$ arrivals of this and 16 prob- 


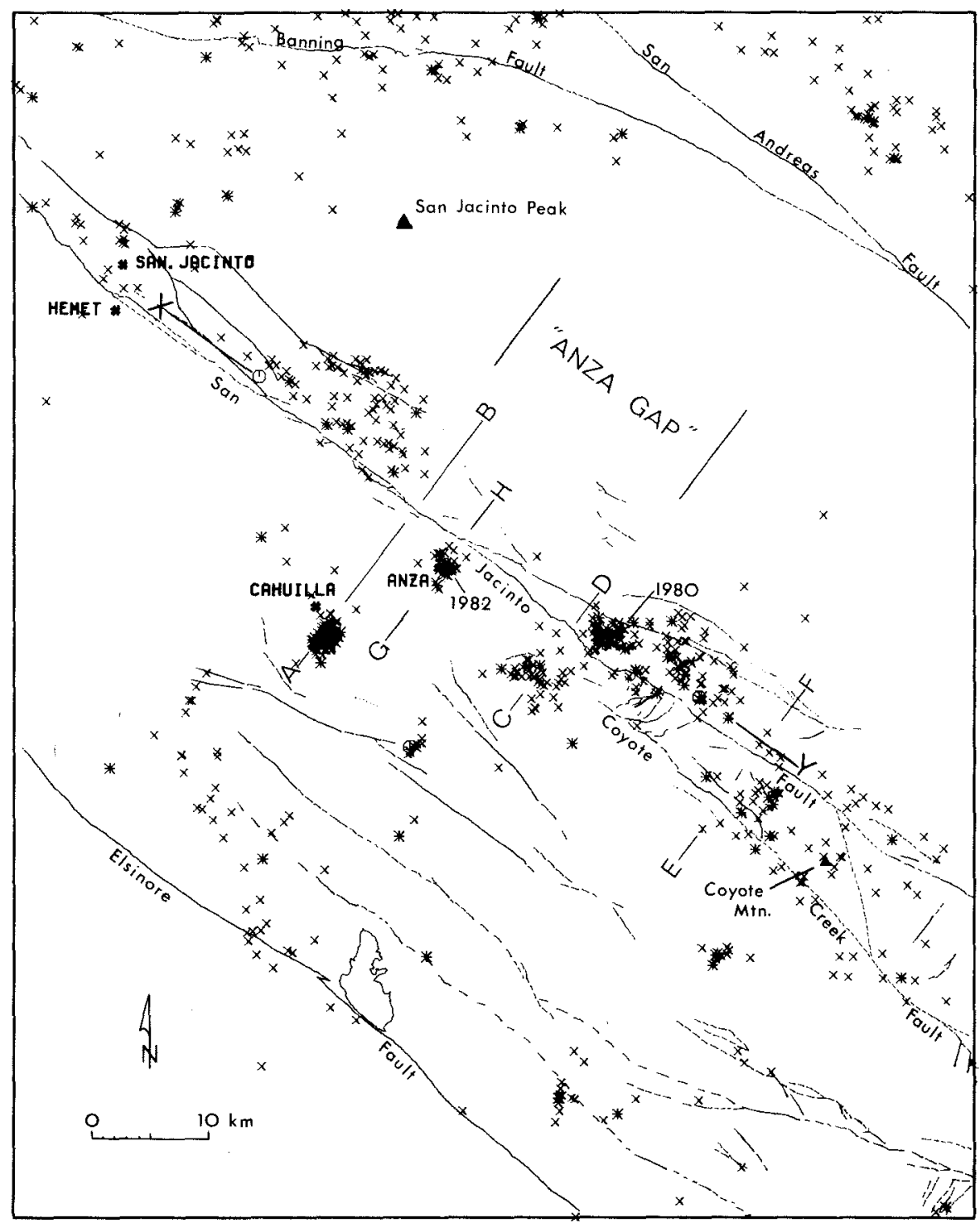

Fig. 3. Map of quality $\mathrm{A}$ and $\mathrm{B}, M \geqslant 2$ earthquakes located during the time period January 1977 to August 1982. The letter pairs A-B, C-D, E-F, G-H, and X-Y indicate the end points of vertical cross sections discussed in the text. Small crosses, $M$ 2-3; asterisk, $M$ 3-4; circle, $M$ 4-5; 1980, $M_{L} 5.5$.

aftershocks. The depth is not constrained since the closest seismograph is $97 \mathrm{~km}$ away; however, a depth of about 8-14 $\mathrm{km}$ is inferred based on the well constrained depths of nearby recent earthquakes.

The $S-P$ times of a dozen of the early larger aftershocks read from Wood-Anderson seismograms recorded at Riverside and La Jolla help constrain the size of the rupture zone. The maximum difference in the $S-P$ times recorded at Riverside (102 km northwest of the main shock on strike with the faults in the epicentral area) is $0.9 \mathrm{~s}$, suggesting that the main rupture zone extended only a few kilometers along strike. Similarly, the 0.2-s difference seen at La Jolla, which is $97 \mathrm{~km}$ distant along a line perpendicular to the faults at the earthquake epicenter, suggests that the aftershock zone was about a kilometer wide. A source less than $10 \mathrm{~km}$ in size was also suggested by Thatcher et al. [1975] based on the variations in $S-P$ times. Direction of rupture propagation can not be resolved.

The first motions at five of the seven conveniently located stations help constrain a focal mechanism, which best fits the local fault geometries and displacement histories, of right slip on a $\mathrm{N}^{\circ} 3^{\circ} \mathrm{W}$ striking, $70^{\circ} \mathrm{NE}$ dipping fault plane (Figure 4, Figure 5, and Table 1, mechanism 1). This fault is most likely the northwest end of the Coyote Creek fault.

Earthquakes in February $1890\left(M_{I} 6.3\right)$ and May 1892 $\left(M_{I}\right.$ 6.3) are poorly located, but a comparison of the reported intensities [Toppozada et al., 1981] with those of the 1937 and 1954 events indicates similar general locations somewhere along the central section of the San Jacinto fault zone. In particular, the 1890 earthquake was reported to be "felt with equal severity in each town on the Southern Pacific line between Pomona and Yuma" [Toppozada et al., 1981]. Since this railroad line runs near the trace of the San Jacinto and San Andreas faults north and east of Riverside, along the Banning fault through San Gorgonio Pass, and near the San Andreas fault east of the Salton Sea, the fact that the earthquake was felt with equal severity all 
along the train route implies that the earthquake did not occur on any of the fault segments near the railroad (such as the December 14, 1948, earthquake which produced widely differing intensities along the train route [Toppozada and Parke, 1982]). The most likely causative structure is near the central San Jacinto fault zone southeast of Anza. The relatively moderate description of the shaking in San Jacinto seems to rule out a location very near San Jacinto or at Anza. This earthquake was probably not generated by the southeastern Elsinore or San Jacinto faults, since a similar sized event on the southeastern San Jacinto fault in October 1942 (Figure 2) produced lower intensities in the Los Angeles County region (intensity map by Toppozada and Parke [1982].

The 1890 earthquake had a local magnitude larger than 6.0 based on a comparison of the areas of intensity $V$ and greater shaking for this and the 1937 earthquake $\left(M_{L} 6.0\right)$.

The May 1892 earthquake had an intensity distribution similar to the February 1890 event. The area of intensity $V$ and greater shaking appears to be the same size for both events suggesting similar magnitudes. The 1892 earthquake, however, had lower intensities in the Los Angeles area, implying a location farther southeast than the 1890 epicenter, possibly in the region of the October 1942 earthquake.

Prior to 1890 the largest reported earthquake possibly associated with the central or northern San Jacinto fault zone occurred on December 16, 1858, and was felt with $M M$ VII-IX intensities near San Bernardino [Toppozada et al., 1981]. This can perhaps be regarded as an aftershock of the great 1857 earthquake which resulted from slip on the San Andreas fault northwest of San Bernardino (K. Sieh, personal communication, 1982).

Since 1899 the time between $M \geqslant 6.0$ earthquakes in the San Jacinto fault zone has been 18, 5, 14, 5, 12, and 14 years, the latest occurring in 1968. The locations and historic accounts of these large events suggest that none have ruptured the Anza seismic gap.

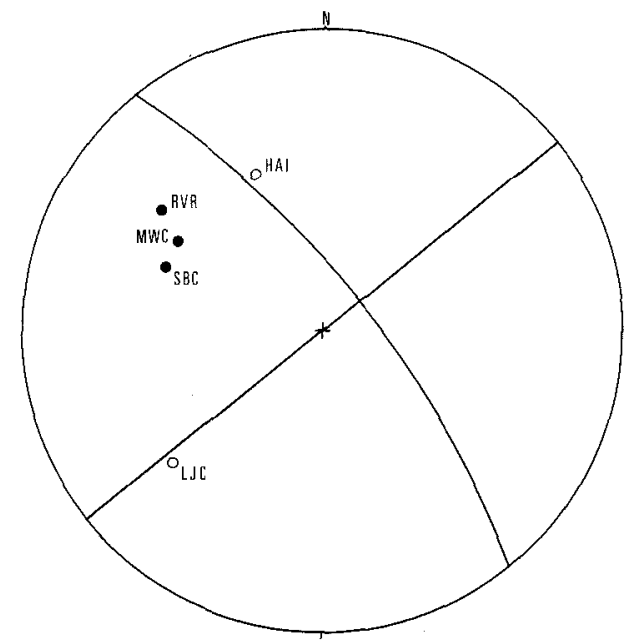

Fig. 4. $P$ wave first motion source mechanism for the 1937 earthquake. The slip is right reverse on a $\mathrm{N} 43^{\circ} \mathrm{W}$ striking, $70^{\circ} \mathrm{NE}$ dipping fault plane. Solid circles, compression; open circles, dilitation. Lower hemisphere projection. The southern California seismograph stations are Haiwee (HAI), Riverside (RVR), Mount Wilson (MWC), Santa Barbara (SBC), and La Jolla (LJC).

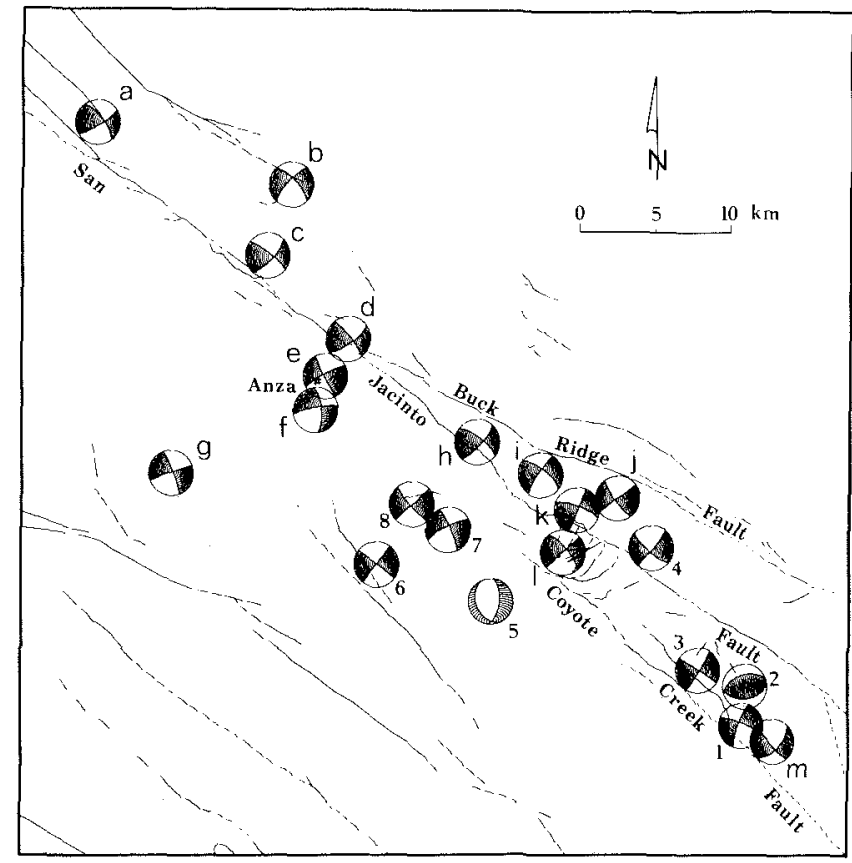

Fig. 5. $P$ wave first motion source mechanisms for selected earthquakes near Anza. Shaded quadrants are compressional. Equalarea projections of the lower hemisphere are shown. Small letters refer to mechanisms discussed in the text. The northwest trending nodal planes of the strike-slip events are constrained to within a few degrees. See Table 1 for more information about these mechanisms.

\section{Geological Aspects of the San Jacinto Fault Zone Near Anza}

Several geologic studies provide constraints on the ages and amounts of movement along the San Jacinto fault system. Significant late Cenozoic right-lateral displacements imply that this fault zone plays an important role in current southern California tectonics. The total offset along the entire zone southeast of Hemet (Figure 1) is $29 \mathrm{~km}$ of right slip since early Tertiary. Right slip of $19 \mathrm{~km}$ is measured on the San Jacinto fault, $5 \mathrm{~km}$ on the Coyote Creek and Box Canyon faults, and $5 \mathrm{~km}$ on the Hot Springs and related faults [Sharp, 1967; Hill, 1981]. The Bautista sedimentary deposits, parts of which contain the 715,000-yearold Bishop Ash [Sharp, 1981], help constrain the timing of recent offsets along the fault. The San Jacinto fault near Anza offsets these deposits at least $5.7 \mathrm{~km}$ right laterally, and the Coyote Ridge block between the San Jacinto and Coyote Creek faults has been pushed up some amount less than $2.4 \mathrm{~km}$ since Bautista deposition (Figure 6) [Sharp, 1967,1975 ]. Offset stream courses show up to $0.72 \mathrm{~km}$ of recent right-slip along the San Jacinto fault near Anza [Sharp, 1967]. Young scarps indicate Holocene to late Pleistocene movement on all faults mentioned above except for the Hot Springs fault [Sharp, 1967, 1972; Hill, 1981]. Shallow thrust faults are present parallel to segments of the San Jacinto and Coyote Creek faults, and small blocks have been thrust at least $0.8 \mathrm{~km}$ outward from the strike-slip faults during Quaternary time [Sharp, 1967].

Geological, seismological, and geodetic data imply a slip rate of about $10-15 \mathrm{~mm} / \mathrm{yr}$ for the San Jacinto fault zone since the mid-Pleistocene and also historically [Sharp, 
TABLE 1. Earthquake Source Mechanisms Determined Near Anza

\begin{tabular}{|c|c|c|c|c|c|c|c|c|}
\hline \multirow{2}{*}{$\frac{\text { Mechanism }}{\mathrm{a}}$} & \multirow{2}{*}{$\begin{array}{c}\text { Date } \\
\text { Aug. } 22,1979\end{array}$} & \multirow{2}{*}{$\frac{\text { UT }}{0201}$} & \multirow{2}{*}{$\frac{\text { Depth,km }}{16.5}$} & \multirow{2}{*}{$\frac{M_{L}}{4.1}$} & \multicolumn{4}{|c|}{ Nodal Planes } \\
\hline & & & & & $\mathrm{N} 37^{\circ} \mathrm{W}$ & $70^{\circ} \mathrm{NE}$ & $\mathrm{N} 54^{\circ} \mathrm{E}$ & $72^{\circ} \mathrm{SE}$ \\
\hline b & Aug. 3,1978 & 0430 & 16.1 & 3.5 & $\mathrm{~N} 46^{\circ} \mathrm{W}$ & $70^{\circ} \mathrm{NE}$ & $\mathrm{N} 40^{\circ} \mathrm{E}$ & $75^{\circ} \mathrm{NW}$ \\
\hline c & July 2, 1977 & 0122 & 13.0 & 3.0 & $\mathrm{~N} 52^{\circ} \mathrm{W}$ & $80^{\circ} \mathrm{NE}$ & $\mathrm{N} 43^{\circ} \mathrm{E}$ & $70^{\circ} \mathrm{SW}$ \\
\hline \multirow[t]{2}{*}{ d } & Nov. 9,1974 & 1010 & 16.8 & 3.2 & $\mathrm{~N} 40^{\circ} \mathrm{W}$ & $80^{\circ} \mathrm{NE}$ & $\mathrm{N} 54^{\circ} \mathrm{E}$ & $72^{\circ} \mathrm{SE}$ \\
\hline & Nov. 9,1974 & 1012 & 19.0 & $3.3^{a}$ & & & & \\
\hline e & June 15,1982 & 2349 & 12.2 & 4.8 & $\mathrm{~N} 27^{\circ} \mathrm{W}$ & $85^{\circ} \mathrm{SW}$ & $\mathrm{N} 62^{\circ} \mathrm{E}$ & $80^{o} \mathrm{NE}^{b}$ \\
\hline \multirow[t]{2}{*}{ f } & Aug. 30,1980 & 2338 & 10.4 & 3.6 & $\mathrm{~N} 06^{\circ} \mathrm{W}$ & $68^{\circ} \mathrm{E}$ & $\mathrm{N} 79^{\circ} \mathrm{E}$ & $80^{\circ} \mathrm{N}$ \\
\hline & Sept. 7, 1980 & - 0326 & 9.2 & 2.7 & & & & \\
\hline g & Feb. 1,1981 & 1927 & 1.0 & 3.4 & $\mathrm{~N} 22^{\circ} \mathrm{W}$ & $82^{\circ} \mathrm{E}$ & $\mathrm{N} 70^{\circ} \mathrm{E}$ & $86^{\circ} \mathrm{NW}^{c}$ \\
\hline $\mathrm{h}$ & Aug. 1, 1975 & 0014 & 12.0 & 4.8 & $\mathrm{~N} 53^{\circ} \mathrm{W}$ & $72^{\circ} \mathrm{NE}$ & $\mathrm{N} 42^{\circ} \mathrm{E}$ & $75^{\circ} \mathrm{SE}^{d}$ \\
\hline i & Feb. 25,1980 & 1047 & 13.5 & 5.5 & $\mathrm{~N} 52^{\circ} \mathrm{W}$ & $68^{\circ} \mathrm{NE}$ & $\mathrm{N} 34^{\circ} \mathrm{E}$ & $10^{\circ} \mathrm{NW}$ \\
\hline $\mathrm{j}$ & May 4,1981 & 1841 & 14.3 & 3.1 & $\mathrm{~N} 37^{\circ} \mathrm{W}$ & $80^{\circ} \mathrm{SW}$ & $\mathrm{N} 53^{\circ} \mathrm{E}$ & $90^{\circ}$ \\
\hline $\mathbf{k}$ & Sept. 16,1979 & 0855 & 9.0 & 3.0 & $\mathrm{~N} 70^{\circ} \mathrm{W}$ & $75^{\circ} \mathrm{N}$ & $\mathrm{N} 22^{\circ} \mathrm{E}$ & $86^{\circ} \mathrm{E}$ \\
\hline 1 & March 25, 1937 & 0849 & & 6 & $\mathrm{~N} 25^{\circ} \mathrm{W}$ & $70^{\circ} \mathrm{NE}$ & $\mathrm{N} 48^{\circ} \mathrm{E}$ & $90^{\circ} \mathrm{SE}$ \\
\hline m & April 28, 1969 & 2320 & 13.0 & 5.8 & $\mathrm{~N} 40^{\circ} \mathrm{W}$ & $80^{\circ} \mathrm{W}$ & $\mathrm{N} 42^{\circ} \mathrm{E}$ & $60^{\circ} \mathrm{E}^{e}$ \\
\hline 1 & Aug. 6,1977 & 1222 & 13.2 & 2.9 & $\mathrm{~N} 68^{\circ} \mathrm{W}$ & $80^{\circ} \mathrm{N}$ & $\mathrm{N} 20^{\circ} \mathrm{E}$ & $78^{\circ} \mathrm{N}$ \\
\hline 2 & May 16,1979 & 0425 & 2.8 & 3.2 & $\mathrm{~N} 72^{\circ} \mathrm{E}$ & $46^{\circ} \mathrm{N}$ & $\mathrm{N} 84^{\circ} \mathrm{E}$ & $45^{\circ} \mathrm{S}$ \\
\hline 3 & Sept. 7, 1979 & 1017 & 2.7 & 3.0 & $\mathrm{~N} 58^{\circ} \mathrm{W}$ & $88^{\circ} \mathrm{SW}$ & $\mathrm{N} 32^{\circ} \mathrm{E}$ & $84^{\circ} \mathrm{SE}$ \\
\hline 4 & Feb. 12, 1979 & 0448 & 3.9 & 4.2 & $\mathrm{~N} 50^{\circ} \mathrm{W}$ & $76^{\circ} \mathrm{SW}$ & $\mathrm{N} 39^{\circ} \mathrm{E}$ & $84^{\circ} \mathrm{SE}$ \\
\hline 5 & April 22, 1979 & 1652 & 12.5 & 3.3 & $\mathrm{~N} 14^{\circ} \mathrm{W}$ & $36^{\circ} \mathrm{W}$ & $\mathrm{N} 07^{\circ} \mathrm{E}$ & $58^{\circ} \mathrm{E}$ \\
\hline 6 & Aug. 1, 1979 & 0831 & 10.5 & 2.8 & $\mathrm{~N} 54^{\circ} \mathrm{W}$ & $90^{\circ}$ & $\mathrm{N} 36^{\circ} \mathrm{E}$ & $90^{o f}$ \\
\hline \multirow[t]{2}{*}{7} & March 10,1980 & 2332 & 11.1 & 3.0 & $\mathrm{~N} 25^{\circ} \mathrm{W}$ & $80^{\circ} \mathrm{NE}$ & $\mathrm{N} 63^{\circ} \mathrm{E}$ & $75^{\circ} \mathrm{NW}$ \\
\hline & Aug. 2, 1979 & 1304 & 10.7 & 2.7 & & & & \\
\hline 8 & Dec. 2,1977 & 1427 & 8.3 & 3.0 & $\mathrm{~N} 43^{\circ} \mathrm{W}$ & $84^{\circ} \mathrm{SW}$ & $\mathrm{N} 47^{\circ} \mathrm{E}$ & $90^{\circ g}$ \\
\hline
\end{tabular}

${ }^{a}$ Same nodal planes as above and similar location.

${ }^{b}$ Also representative of two large aftershocks, $M_{L} 3.0$ and 3.3, in the following half hour.

${ }^{c}$ Also representative of 17 other swarm events, $M_{L}$ 1.4-3.7, from June 1978 to May 1982.

${ }^{d}$ From Hartzell and Brune [1979].

${ }^{e}$ From Thatcher and Hamilton [1973].

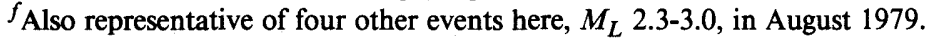

${ }^{g}$ Also representative of two other events in this area, $M_{L} 2.6$ (October 6, 1978) and 2.9 (July 3, 1978).

1967, 1981; Brune, 1968; Thatcher et al., 1975; Savage and Prescott, 1976; King and Savage, 1983]. This slip rate is less than those observed along several segments of the nearby San Andreas fault, including the $32 \mathrm{~mm} / \mathrm{yr}$ historic creep rate between Cholame and Hollister [Burford and Harsh, 1980], $32 \mathrm{~mm} / \mathrm{yr}$ historic slip rate between San Juan Bautista and Slack Canyon [Lisowski and Prescott, 1981], and Holocene slip rates of $34 \mathrm{~mm} / \mathrm{yr}$ in the Carrizo Plain [Sieh and Jahns, 1983] and $25 \mathrm{~mm} / \mathrm{yr}$ at Cajon Pass [Weldon and Sieh, 1981; R. Weldon and K. Sieh, personal communication, 1982].

The significant geological features in the Anza area include the discontinuous and convergent fault geometries, the shallow thrust faults parallel to short segments of the fault zone, and the upthrown Coyote Ridge block. The fault geometries indicate a narrowing of the fault zone from $11 \mathrm{~km}$ wide across the active Buck Ridge, San Jacinto, and Coyote Creek faults to $1.5 \mathrm{~km}$ near Anza (Figure 1). Since all of these faults show considerable right-lateral offset and also recent movement, this constriction of the fault zone must result in additional compression normal to the faults as material is displaced into the constricted area. The uplift of the Coyote Ridge block between the San Jacinto and Coyote Creek faults is an example of the transverse shortening in this area due to the convergent faults (Figure 6). This uplift is even more interesting since it is situated where a depression or graben would be expected due to the right step from the northwest end of the Coyote Creek fault to the San Jacinto fault. Several steplike, listric, normal faults oriented perpendicular to the lateral slip faults at the northwest end of Coyote Ridge testify to the extensional strain regime near the right step [Sharp, 1967, 1975], but these are superimposed upon the Coyote Ridge horst.

The shallow thrust faults along the San Jacinto fault just northwest and southeast of Anza [Sharp, 1967, Plate 1 and Figure 3] appear to be manifestations of the lateral shortening in this area as material is squeezed out of the fault zone. The thrust faults along the San Jacinto fault show Mesozoic crystalline rocks thrust over Pleistocene sedimentary deposits. Where exposed the shallow dipping thrust planes progressively steepen with depth suggesting that the faults become vertical at a relatively shallow depth [Sharp, 1967, Figure 3]. These are probably comparable to

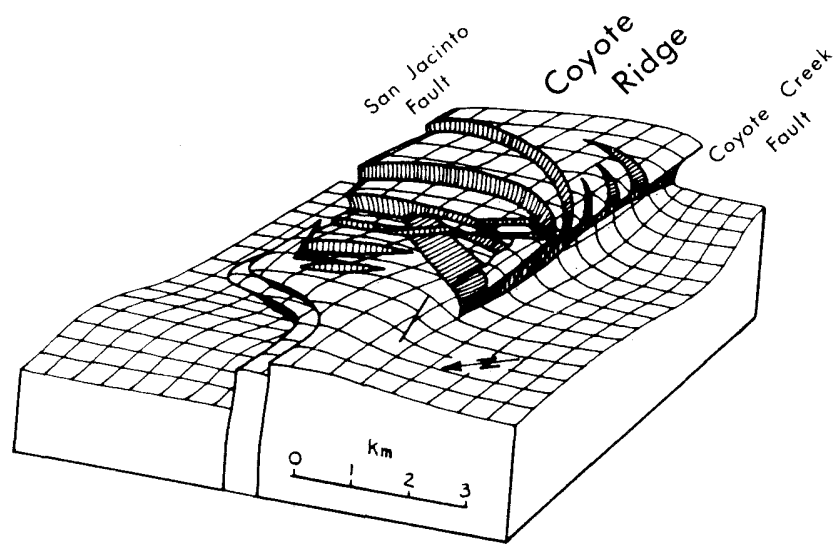

Fig. 6. Diagramatic sketch of extensional faults superimposed on the Coyote Ridge uplift block between the Coyote Creek and San Jacinto faults [after Sharp, 1975]. 


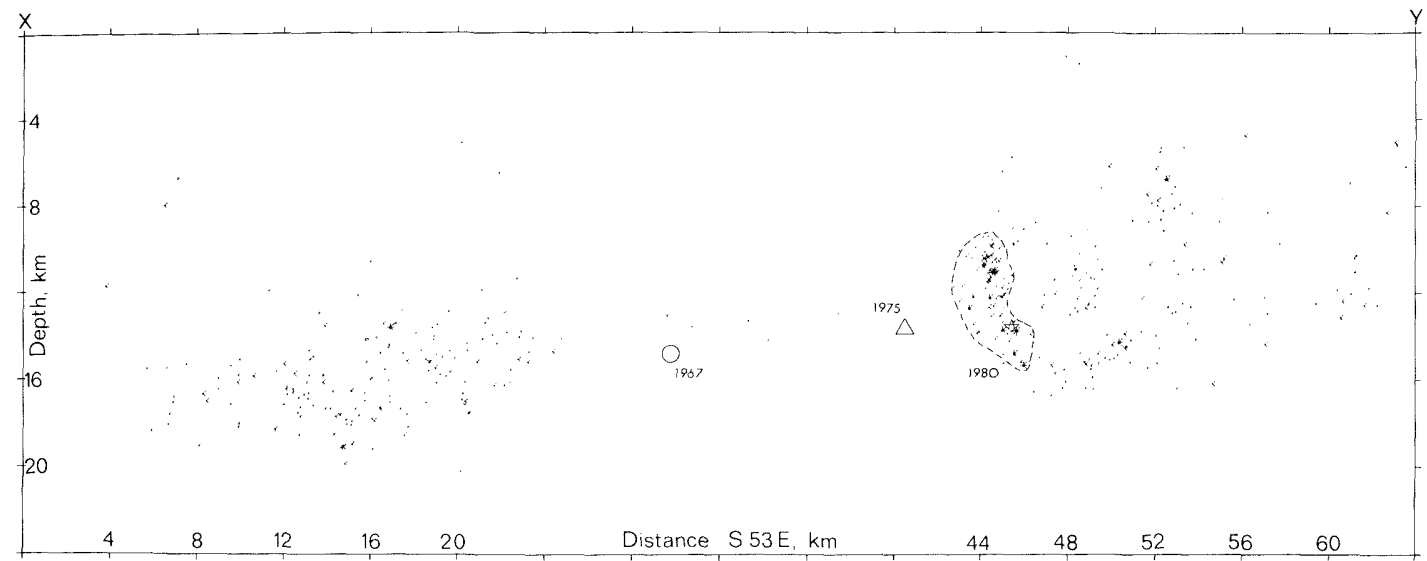

Fig. 7. Vertical section along line X-Y (Figure 3) parallel to the San Jacinto fault centered on the Anza seismic gap with locations of all quality A and B earthquakes which occurred during the time period January 1980 to June 1982. Only earthquakes located northeast of the surface trace of the San Jacinto fault are plotted. The locations of the 1967 and 1975 earthquakes are indicated, and the aftershock zone of the 1980 earthquake is outlined. Small crosses, $M$ 0-2; crosses, $M$ 2-3; asterisks, $M$ 3-4, star, $M_{L}$ 5.5.

the thrust-slide blocks which have squeezed out along the San Andreas fault just northwest of the intersection with the Garlock fault [Davis and Duebendorfer, 1982].

Shallow thrust faults are also mapped along the northwest end of the Coyote Creek fault where crystalline rocks of Coyote Ridge are thrust southwest over Quaternary deposits. These faults are discussed later in an analysis of the northwest end of the Coyote Creek fault.

\section{Seismictity Near the ANZa Gap}

The details of the current seismicity near Anza were studied using the earthquake locations provided by the California Institute of Technology-U.S. Geological Survey (Caltech-USGS) Southern California Seismic Network (SCARLET). The location uncertainty for most earthquakes of the past few years in the Anza area is less than a kilometer, and the catalog since about 1976 is reasonably complete for earthquakes with magnitudes greater than 2 .

The most apparent feature on an epicenter map of the Anza area is the $20-\mathrm{km}$-long aseismic fault segment bounded to the northwest and southeast by areas of high earthquake activity [Kanamori, 1980; Sanders et al., 1981] (Figure 3). The broad active areas may be due to high stress concentrations at the transition from slipping to locked fault segments. The small earthquake activity in these two areas (especially the southeast area) seems to have increased significantly since the mid-1970's, suggesting that the present high seismicity has not been a permanent feature of these areas and instead may be due to recent stress increases. The recently increased rate of earthquake occurrence is also apparent from the distribution of $M_{L} 3$ and larger earthquakes located in these areas since 1934.

The subsurface expression of the aseismic zone is shown in the fault-parallel cross section Figure 7. Earthquakes occur deeper northwest of the Anza gap possibly due to the load produced by the great mass of the San Jacinto Mountains (Figures 1 and 3). The increased compressional stress resulting from this load may depress the brittle-ductile failure transition deeper along this portion of the fault Some researchers [Meissner and Strehlau, 1982; Sibson,
1982] have suggested that the maximum depth of earthquakes in an area is controlled predominantly by the regional heat flow and the elastic properties of mineral assemblages in the upper crust. In this case local effects may be controlling the maximum depth variation of earthquakes near Anza, since the variation occurs over such a short distance.

\section{Subsurface Fault Structure}

The gross structure at depth of the major faults can be determined using the quality A and B earthquake locations for the past several years. Figures 8,9 , and 10 are transverse vertical sections across three segments of the fault zone near Anza. The hypocentral locations of small earthquakes suggest that the San Jacinto fault dips roughly the same throughout this area at about $85^{\circ}$ to the northeast. Earthquake focal mechanisms support this direction of dip (Figure 5, mechanisms a,c,d,h,k). The Buck Ridge fault appears to be vertical to steeply southwest dipping (also see Figure 5, mechanism $\mathrm{j}$ ) which is consistent with the linear topographic expression of this fault [Sharp, 1967]. The dip of the Coyote Creek fault is less clear, but in the $18-\mathrm{km}$ segment extending northwest from the Coyote Mountain region (Figure 3) the fault appears to be vertical to steeply northeast dipping (Figure 10). A near-vertical dip is also implied by the linear topographic expression of the fault and the nature of the Bouguer gravity anomaly over the fault [Sharp, 1967]. The northwest termination of the Coyote Creek fault is relatively aseismic, and thus subsurface geometry is not easily determined. The earthquakes which lie northwest of the end of the surface trace of the Coyote Creek fault (Figure 3) do not appear in cross section (Figure 9) to lie on the fault at depth and rather may be due to stress concentrations off the end of the fault.

Clues to the possible dip of the northwest Coyote Creek fault have been revealed in a recent study by Given [1982; and personal communication, 1982]. He used a master event earthquake relocation technique to study the subsurface fault structure in the area of the $1980 M_{L} 5.5$ earthquake (Figure 3). Details in the earthquake sequence and 


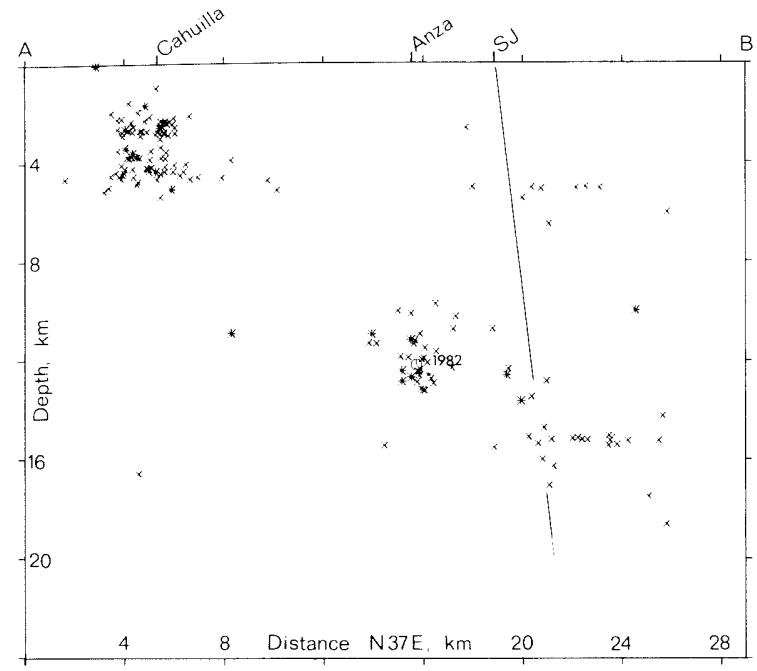

Fig. 8. Vertical section along line A-B (Figure 3). Maximum projection distance is $10 \mathrm{~km}$. The dip of the San Jacinto fault (SJ) is inferred from focal mechanisms of small to moderate earthquakes on the fault and alignments of hypocenters of earthquakes northwest and southeast of the Anza quiescent segment. Crosses, $M$ 2-3; asterisks, $M$ 3-4; circle, $M$ 4-5, star, $M_{L} 5.5$.

the orientation of the well-constrained focal mechanism of the main shock (Figure 5, mechanism i) suggest that some of the fault rupture was on a $70^{\circ} \mathrm{NE}$ dipping fault plane which extends updip to the surface trace of the Coyote Creek fault. A dip of this angle for the northwest Coyote Creek fault implies that it and the San Jacinto fault merge at about $12 \mathrm{~km}$ depth. This is consistent with the idea that fault motion is transferred from the San Jacinto fault to the Coyote Creek fault in this area [Sharp, 1975; Given, 1982]. The Coyote Creek fault seems to be near vertical farther southeast (Figure 10), suggesting that the faults merge only at the northwest end of the Coyote Creek fault. This particular fault geometry beneath the northwest end of Coyote Ridge implies the existence of a steep, northeast dipping ramp which may aid in the uplift of the Coyote Ridge block.

The northwesternmost $10-\mathrm{km}$ segment of the Coyote Creek fault is not similar in nature to the fault farther southeast. Rather than expressing itself as a linear, relatively simple fault trace the northwestern segment "is marked by a broad and very complex zone of fracturing involving many branching faults and thrusts" [Sharp, 1967, p. 711]. The crystalline rocks of Coyote Ridge are being, in part, thrust southwest over Quaternary sedimentary deposits [see Sharp, 1967, Plate 1]. This change in character of the surficial expression of the northwest end of the Coyote Creek fault may be indicative of a similar change in the character of the fault at depth, that is a shallower dipping fault plane and possible northward rotation of fault strike towards the San Jacinto fault.

\section{Recent Moderate Earthquakes Near the Anza Gap}

Since 1967 two earthquakes of $M_{L} 4.8$, one $M_{L} 4.7$, and one $M_{L} 5.5$ have occurred in and near the Anza seismic gap. The locations and aftershock distributions of these earthquakes are important for understanding the nature of this fault segment.

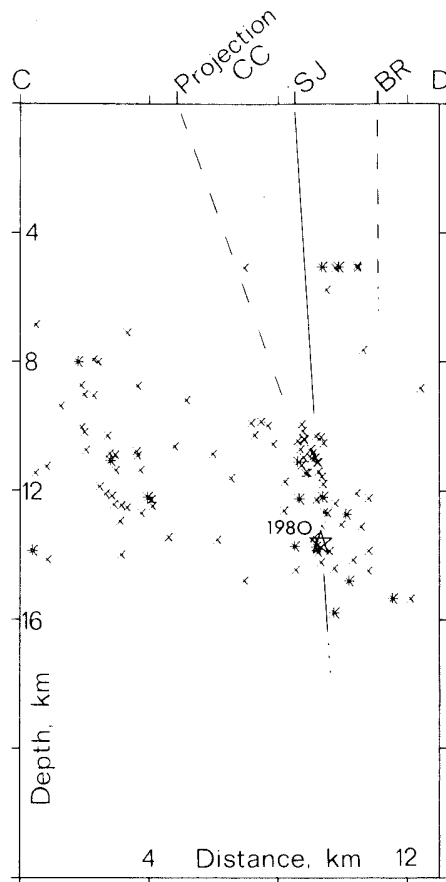

Fig. 9. Vertical section along line C-D (Figure 3). Maximum projection distance is $5 \mathrm{~km}$. CC, Coyote Creek fault; SJ, San Jacinto fault; BR, Buck Ridge fault. Crosses, $M$ 2-3; asterisks, $M$ 3-4; star, $M_{L} 5.5$.

We relocated the May 21, 1967, $M_{L} 4.7$ earthquake relative to seven recent well-located earthquakes. The revised hypocenter places the earthquake about $14 \mathrm{~km}$ deep on the San Jacinto fault near the center of the Anza gap (Figures 2 and 7). The largest aftershock, $M_{L}$ 2.5, which happened the next day, occurred about $10 \mathrm{~km}$ northwest of the main shock. A crude main shock focal mechanism based on five first motions is consistent with right slip on a nearly vertical fault striking $\mathrm{N} 50^{\circ} \mathrm{W}$. This is similar to the mechanism obtained for two recent small earthquakes in the same location (Figure 5, mechanism d).

The microearthquakes which occurred in this area both

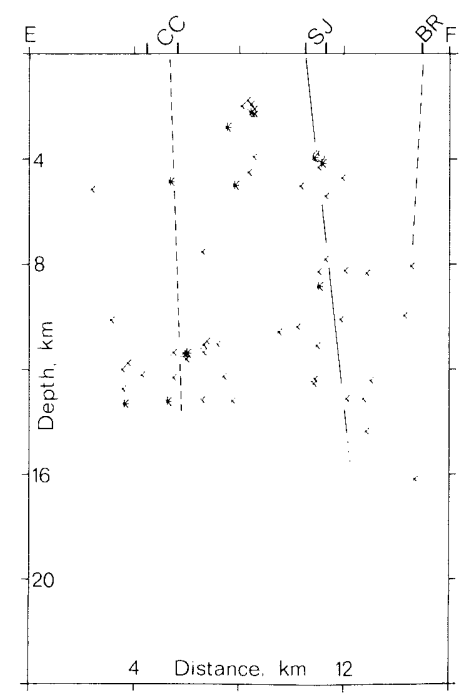

Fig. 10. Vertical section along line E-F (Figure 3). Maximum projection distance is $7.5 \mathrm{~km}$. Crosses, $M$ 2-3; asterisks, $M$ 3-4; circle, $M$ 4-5, star, $M_{L} 5.5$. 


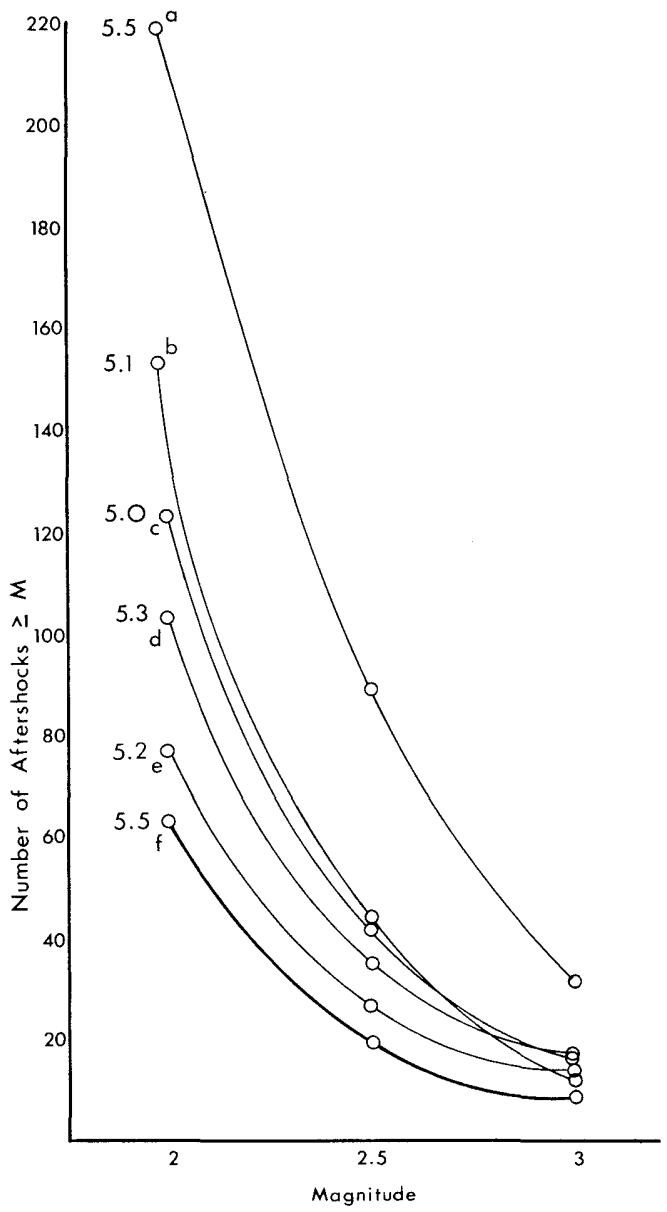

Fig. 11. Plot of the number of $M_{L} \geqslant 2-3$ aftershocks which occurred in one month after the southern California earthquakes listed in Table 2. The magnitude of each event is indicated, as is the letter reference to Table 2 . The heavier curve indicates the Anza earthquake aftershocks. Note that the Anza event had fewer aftershocks even though its local magnitude is greater than or equal to the other main shock magnitudes. The number of aftershocks following moderate earthquakes may indicate the level of stress normal to the fault plane.

before and after the $M_{L} 4.7$ earthquake were located by Arabasz et al. [1970] using a portable microearthquake array of seven stations. Their array was operated before the earthquake for 3 weeks during the summer of 1966 and then after the earthquake from May 24 to 31 and June 13 to 20,1967. Unfortunately, the epicenters of the $M_{L} 4.7$ earthquake and closest aftershocks were not contained within this array, so small aftershocks in the immediate epicentral area are not included in their presentation [see $\mathrm{Ara}$ basz et al., 1970, Figure 2]. Their data, though, show the aseismic nature of the southeast portion of the gap to the microearthquake level. A vertical section in their paper [see Arabasz et al., 1970, Figure 3] indicates that of the six small earthquakes which occurred within the gap, five are shocks which occurred after the larger nearby event. Such a small number of microearthquakes in the gap from 3 days to a month after this event seem to be suggestive of the locked nature of the fault.

Two recent earthquakes similarly indicate the seismogenic but locked nature of the Anza gap. These occurred on August 2, $1975\left(M_{L} 4.8\right)$, and February 25, $1980\left(M_{L}\right.$ 5.5 ), and both were located on the San Jacinto fault in the southeast end of the gap (Figures 2 and 7). The 1980 earthquake shows expansion of rupture upward and to the northwest into the gap, and the mechanisms of the 1975 and 1980 events indicate right slip on the steeply northeast dipping San Jacinto fault (Figure 5, mechanisms h and i). Both earthquakes had relatively few aftershocks for their size $\left(1975\right.$, five $M_{L}>2.5 ; 1980,19 M_{L}>2.5$, in 1 month). Figure 11 and Table 2 show the small number of $M_{L} 2-3$ aftershocks of the 1980 earthquake relative to several other southern California earthquakes of similar size. The 1980 aftershock zone is $3 \mathrm{~km}$ long and $6 \mathrm{~km}$ thick (where "thick" indicates the downdip width of the aftershock zone). By comparison, the 1966 Parkfield earthquake $\left(M_{L} 5.5\right)$, which was located on a portion of the San Andreas fault that is creeping (implying relatively low fault strength), had 89 $M_{L}>2.5$ aftershocks, a large number of bigger aftershocks, and an extensive aftershock area $(27 \mathrm{~km}$ long and $13 \mathrm{~km}$ deep) [McEvilly et al., 1967].

The source of the 1975 earthquake was studied by Hartzell and Brune [1979]. By comparing local body wave and teleseismic surface wave moments and by studying the distribution and signals of the main shock and aftershocks they concluded that this earthquake had two-stage stress release with an initial rupture of 225 bars stress drop over $0.5-\mathrm{km}$ source radius and a total rupture of 90 bars over 1$\mathrm{km}$ radius. These observations indicate localized stress concentrations in the Anza gap.

TABLE 2. Number of Aftershocks Following Some $M_{L}$ 5.0-5.5 Southern California Earthquakes

\begin{tabular}{|c|c|c|c|c|c|c|c|}
\hline \multirow[b]{2}{*}{ Name } & \multirow[b]{2}{*}{ Date } & \multirow[b]{2}{*}{ Latitude,Longitude,deg } & \multirow[b]{2}{*}{$M_{L}$} & \multicolumn{3}{|c|}{ Number of Aftershocks } & \multirow{2}{*}{$\begin{array}{c}\text { Source } \\
\text { Mechanism }\end{array}$} \\
\hline & & & & $\overline{M_{L}>2}$ & $>2.5$ & $>3$ & \\
\hline a Parkfield & June 28, 1966 & $35.955,-120.498$ & 5.5 & 220 & 88 & 30 & right-lateral \\
\hline b Santa Barbara & Aug. 13,1978 & $34.347,-119.696$ & 5.1 & 153 & 42 & 11 & thrust \\
\hline c Malibu & Jan. 1,1979 & $33.945,-118.682$ & 5.0 & 122 & 41 & 15 & thrust \\
\hline d Catalina & Sept. 4, 1981 & $33.671,-119.111$ & 5.3 & 102 & 34 & 16 & right-lateral \\
\hline e Galway & June 1,1975 & $34.516,-116.496$ & 5.2 & 76 & 25 & 13 & right-lateral \\
\hline f Anza & Feb. 2, 1980 & $33.505,-116.514$ & 5.5 & 62 & 18 & 8 & right-lateral \\
\hline
\end{tabular}

These events were chosen for comparison because they and their aftershocks are well located, and most of the aftershocks larger than $M_{L} 2$ are cataloged. The aftershocks are defined as those earthquakes occurring after the main shock (for this study we chose a 1 -month time period) whose epicenters locate on a continuous trend which includes the main shock. Most of the events have rightlateral source mechanisms, and their aftershocks have trends consistent with the local fault strikes. Earthquakes not associated with the rupture zone are readily identified. The Santa Barbara and Malibu earthquakes have thrust source mechanisms, and their aftershock zones are relatively broad; however, there is little difficulty in distinguishing small earthquakes not associated with the continu-
ous rupture zone. 


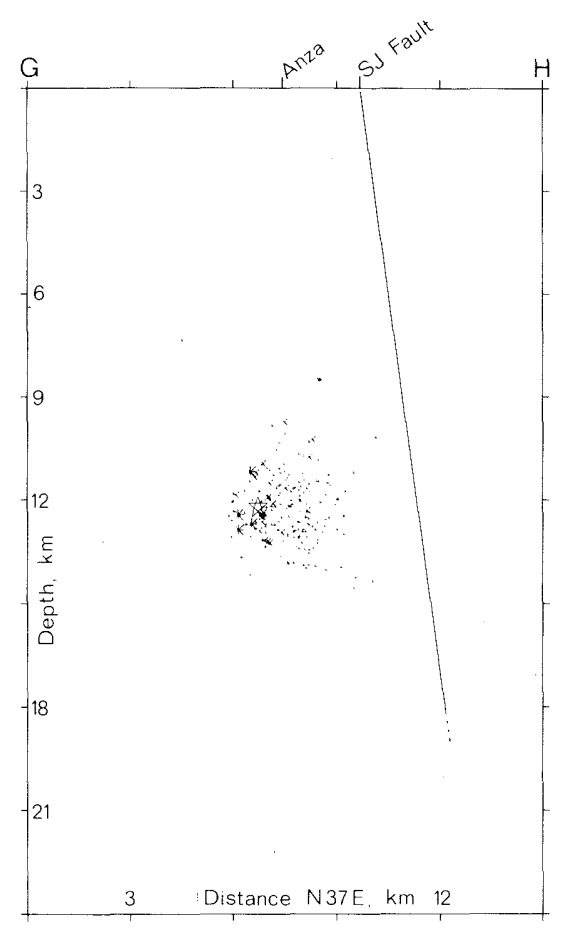

Fig. 12. Vertical section along line G-H (Figure 3) showing the location of the June $15,1982, M_{L} 4.8$ earthquake (star) and aftershocks relative to the inferred extension of the San Jacinto fault at depth. Small pluses, $M$ 0-2; crosses, $M$ 2-3; asterisks, $M$ 3-4.

The June 15, 1982, $M_{L} 4.8$ earthquake is the most recent moderate earthquake to occur near the Anza seismic gap. This earthquake was produced by rupture at a depth of $12 \mathrm{~km}$ directly beneath the town of Anza and is not associated with a mapped fault trace (Figure 3). The earthquake and aftershocks did not occur on the throughgoing Sản Jacinto fault, since it dips steeply northeast here, but in the block just southwest (Figures 8 and 12). The hypocenters of the main shock and largest aftershocks define a vertical plane striking $\mathrm{N} 26^{\circ} \mathrm{W}$. This is in agreement with the well-constrained focal mechanism of the main shock (Figure 5, mechanism e) and mechanisms of several larger aftershocks. Within the first 3 days the aftershocks with $M_{L} \geqslant 2$ define a tight rupture zone $2.5 \mathrm{~km}$ long, $1.5 \mathrm{~km}$ wide, and $3 \mathrm{~km}$ thick. During this same time period, microearthquakes extend $3 \mathrm{~km}$ northeast toward the San Jacinto fault (Figure 12). This event had seven aftershocks of $M_{L} \geqslant 2.5$ in the following month. No aftershocks occurred on the San Jacinto fault proper even though the main shock was only $4 \mathrm{~km}$ distant.

These four earthquakes in and near the Anza seismic gap reveal important information about the stress conditions in the gap. The 1982 earthquake and aftershocks represent local fracturing and stress release as strain increases around the locked fault. The three other moderate earthquakes on the San Jacinto fault in the gap testify to the seismogenic and highly stressed but locked nature of the fault here. These three earthquakes can be pictured as resulting from the rupture of small asperities on the fault as stress increases in the gap. Aftershocks of these events may be limited in size and extent by adjacent stronger asperities. The size and number of these stronger asperities and the time sequence of their rupture will prob- ably determine the magnitudes of the earthquakes which relieve the built-up strain in the gap. If the entire $20-\mathrm{km}$ long quiescent segment ruptures, a magnitude 6.5 earthquake can be expected based on comparison with other historic strike-slip earthquakes and their rupture lengths [Slemmons, 1977]. Historically, the size of the seven large earthquakes generated by the faults in the San Jacinto fault zone has been limited to $M$ 6-7 (possibly due to the segmented nature of the fault zone). Thus, if rupture were to propagate out of the Anza area, we would not expect an earthquake larger than $M 7$.

\section{The 1968 Borrego Mountain and 1969 Coyote Mountain EARTHQUAKES}

Detailed analysis of the Borrego Mountain and Coyote Mountain earthquakes reveals much about the character of the south-central San Jacinto fault zone. The nature of this area is important in understanding the southeast end of the Anza gap, since significant geologic features are continuous from Coyote Mountain to near Anza.

The Borrego Mountain earthquake $\left(M_{L}\right.$ 6.8) of April 28,1968 , occurred on the southern extension of the Coyote Creek fault (Figure 2). Seismicity of the 8 years prior to the main shock has been relocated by Corbett and McNally [1978; E. Corbett, personal communication, 1982], who found two clusters of small earthquakes that preceded the main shock by several years. These clusters occurred in the crustal blocks northeast and southwest of the Coyote Creek fault. Both were $10-15 \mathrm{~km}$ from the fault in a direction nearly perpendicular to the fault at the eventual main shock epicenter (Figure 13). The southwest cluster was active during late summer 1961 and winter 1962-1963, and the northeast cluster was active during late summer 1965, nearly 3 years before the main shock. The only foreshock $\left(M_{L} 3.7\right)$ occurred about 1 minute before and in nearly the same location as the main shock.

The aftershocks associated with this earthquake have been analyzed by Hamilton [1972] and Allen and Nordquist [1972]. Most of the aftershocks are located parallel to the northwest trending surface rupture and slightly to the northeast, suggesting a steeply northeast dipping fault plane (Figure 13). The aftershock zone extended northwest and southeast from the main shock, but aftershocks were much more numerous to the southeast. There is a 6-km gap in the aftershock pattern where the main shock is located. This is consistent with complete stress release on a $8-\mathrm{km}$ diameter source area due to the breaking of an asperity [Ebel and Helmberger, 1982]. The aftershock distribution is similar to the distribution of surface rupture which extended about $7 \mathrm{~km}$ northwest and $25 \mathrm{~km}$ southeast from the main shock epicenter. Aftercreep was reported southeast of the main shock for at least 1000 days following the earthquake, more than doubling the initial slip on portions of the central break [Burford, 1972]. Creep has continued on the Coyote Creek fault here at least since 1971 at an average rate of $5.8 \mathrm{~mm} / \mathrm{yr}$ (C. Allen, personal communication, November 1982).

Figure 14a is a cross section parallel to the Coyote Creek fault showing the combined aftershocks of the Borrego Mountain and Coyote Mountain earthquakes. One of the striking features of the distribution of hypocenters is 


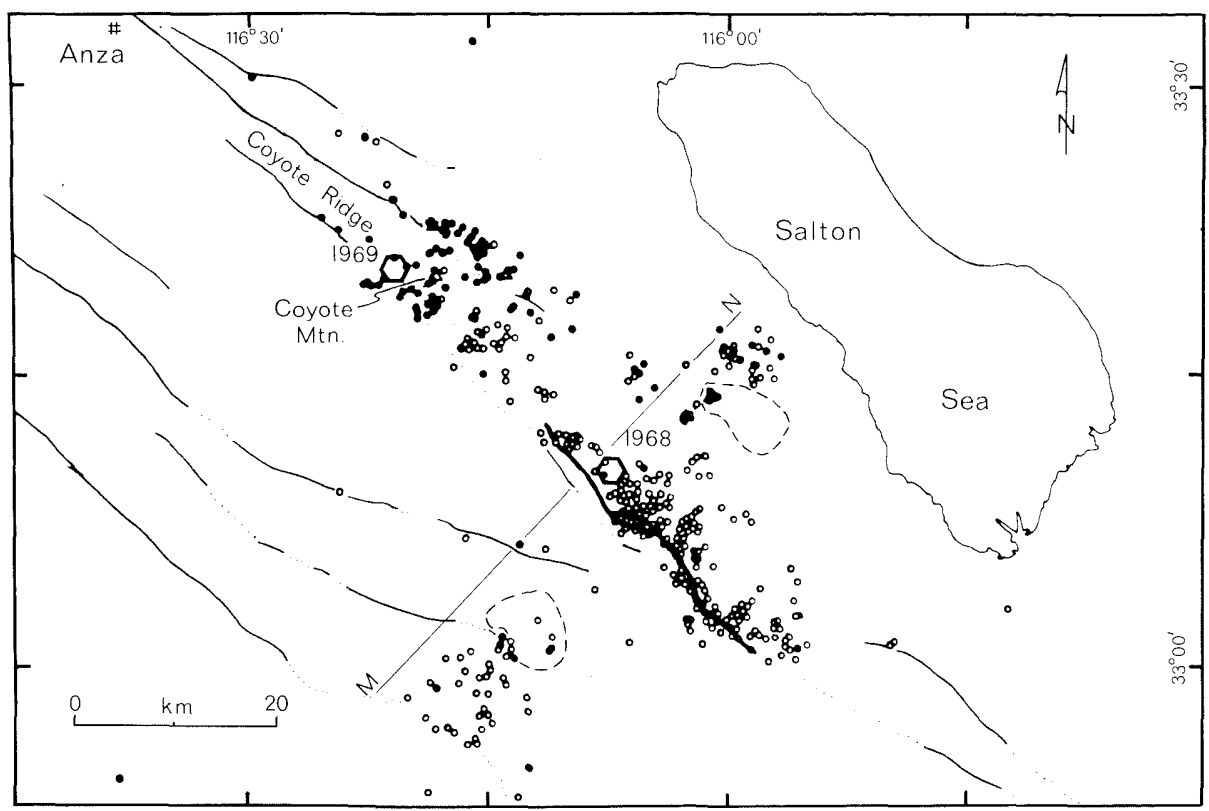

Fig. 13. Main shock epicenters (hexagons) and combined aftershocks of the 1968 Borrego Mountain (open circles) and the 1969 Coyote Mountain (solid circles) earthquakes. The heavy fault line is the 1968 surface rupture. The dashed outlined areas indicate the locations of "preshock" clusters preceding the 1968 earthquake [Corbett and McNally, 1978] [after Thatcher and Hamilton, 1973].

the abrupt termination of the Borrego Mountain aftershock zone to the northwest, perhaps suggesting that rupture was stopped by a barrier. This abrupt end coincides with the southeast extent of the Coyote Ridge uplift block (Figures 6 and 13). The few Borrego Mountain aftershocks which do occur farther northwest are in the eventual rupture area of the Coyote Mountain event.

The aftershocks of the 1969 Coyote Mountain earthquake $\left(M_{L} 5.8\right)$ were analyzed by Thatcher and Hamilton [1973]. They found relatively few aftershocks compared to other events of similar magnitude (five $M_{L} \geqslant 2.5$ in 1 month). The aftershocks were distributed about equally on the Coyote Creek and adjacent San Jacinto faults (Figure 13). The main shock ruptured at a depth of about $12 \mathrm{~km}$ on the Coyote Creek fault. The aftershocks which occurred on the Coyote Creek fault were some of the largest and extended southeast from the main shock at depths between 10 and $14 \mathrm{~km}$. The main shock and aftershocks on the Coyote Creek fault define a rupture zone $9 \mathrm{~km}$ long by 4 $\mathrm{km}$ thick. A very high percent of these aftershocks were deep [see Sibson, 1982, Figure 3], suggesting that rupture was not allowed to propagate to shallower depths due to high normal stresses from the uplift Coyote Ridge block. Teleseismic short-period $P$ wave spectra indicate that the main shock was a high stress drop event on a small source area [Thatcher and Hamilton, 1973]. The fairly wellconstrained focal mechanism (Figure 5, mechanism m) shows a component of normal faulting as well as right slip on a steeply southwest dipping, $\mathrm{N} 40^{\circ} \mathrm{W}$ striking fault. This fault movement is consistent with relative uplift of the Coyote Mountain block as well as regional right-lateral shear. No preshock or foreshock activity is apparent before this earthquake, since these events cannot be distinguished from the Borrego Mountain aftershocks.

The above seismological data demonstrate that the character of the Coyote Creek fault changes where the fault leaves Borrego Valley and becomes a bounding fault for the Coyote Mountain-Coyote Ridge block. In the vicinity of the Borrego Mountain earthquake and aftershocks the fault is in a region of apparently less strong local compression. The extended aftershock zone of the Borrego Mountain earthquake and the prolonged afterslip and continuing fault creep on the southern two thirds of the fault rupture are consistent with a relatively weaker fault here. Along the Coyote Ridge uplift, however, local compressive stresses normal to the Coyote Creek fault seem to be greater, possibly reflected in the abrupt northwest termination of the 1968 Borrego Mountain aftershocks at the southeast end of Coyote Ridge and the high stress drop and limited, deep aftershocks of the 1969 Coyote Mountain event. The geological and seismological evidence indicates that this local more compressive stress regime continues northwest on the Coyote Creek and San Jacinto faults past Buck Ridge and through the Anza gap, becoming less compressional again near Hemet. Mechanisms of small earthquakes on the San Jacinto fault near Anza and Hemet are consistent with this later observation and show strike-slip and thrust movement near Anza (Figure 5) [Pechmann, 1983, Figure 3-11] and some normal movement near Hemet [Pechmann, 1983, Figure 3-10].

\section{The Cahutlla Swarm Area}

Four months following the February $25,1980, M_{L} 5.5$ earthquake a swarm of small earthquakes commenced beneath Cahuilla Valley, $10 \mathrm{~km}$ southwest of Anza (Figure 3). This swarm is interesting for several reasons including the time-space occurrence of the swarm relative to other moderate earthquakes in the area, the orientations of source mechanisms of small earthquakes in the swarm, the similarity in relative location of this swarm and the 1968 Borrego Mountain earthquake "preshocks," and the prior 


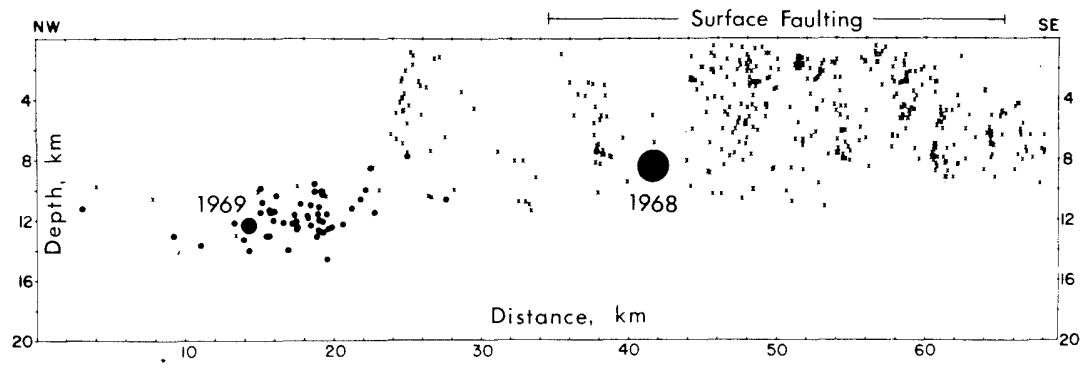

a

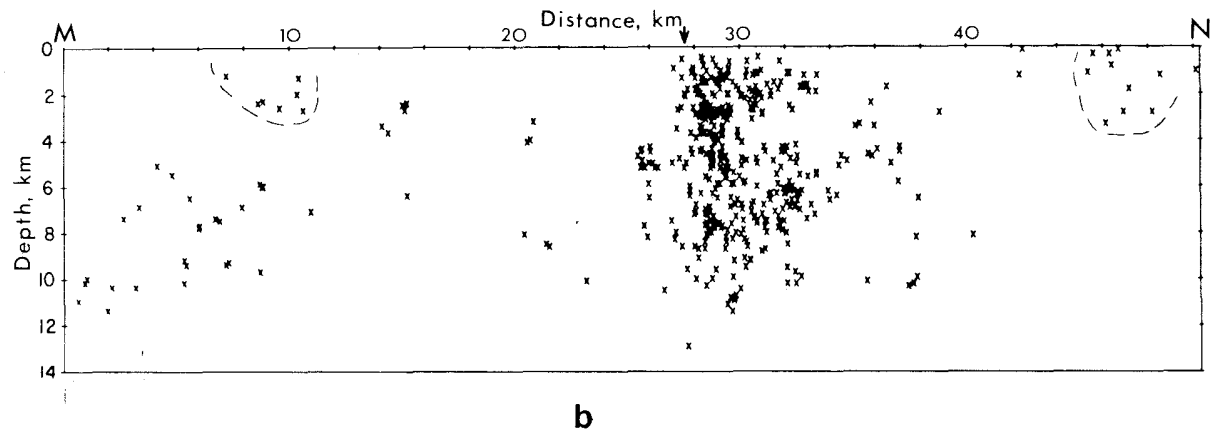

Fig. 14. (a) Vertical section parallel to the aftershock zones of the Borrego Mountain (crosses) and Coyote Mountain (dots) earthquakes. The 1968 and 1969 main shock locations are shown. The extent of the 1968 surface rupture is indicated [after Thatcher and Hamilton, 1973]. (b) Vertical section M-N (Figure 13) perpendicular to the 1968 rupture zone. The dashed outlines enclose the shallow aftershocks discussed in the text. The arrow indicates the position of the surface fault trace [after Hamilton, 1972].

history of increased earthquake activity in this same location before the $1918(M 6.8)$ and $1937\left(M_{L} 6.0\right)$ events. The swarm earthquakes occupy a volume that extends $5 \mathrm{~km}$ north-south, $3 \mathrm{~km}$ east-west, and from 2 to $5 \mathrm{~km}$ in depth (Figure 8).

Small earthquake activity in the swarm was relatively constant from July 1980 through October 1981 with a peak of activity from October 1980 to March 1981. Since November 1981 the earthquakes have become less frequent and the magnitudes small. The maximum magnitudes determined were near $M_{L} 3.7$.

Figure 15 shows the time-space relationships between the Cahuilla swarm, the $1980 M_{L} 5.5$ earthquake, and the June $15,1982, M_{L} 4.8$ earthquake. Since 1975, when microearthquake location accuracy improved, but before July 1980, the Cahuilla area had been relatively quiet. The timing of the swarm, which began 4 months after the 1980 earthquake and ended 7 months before the June 1982

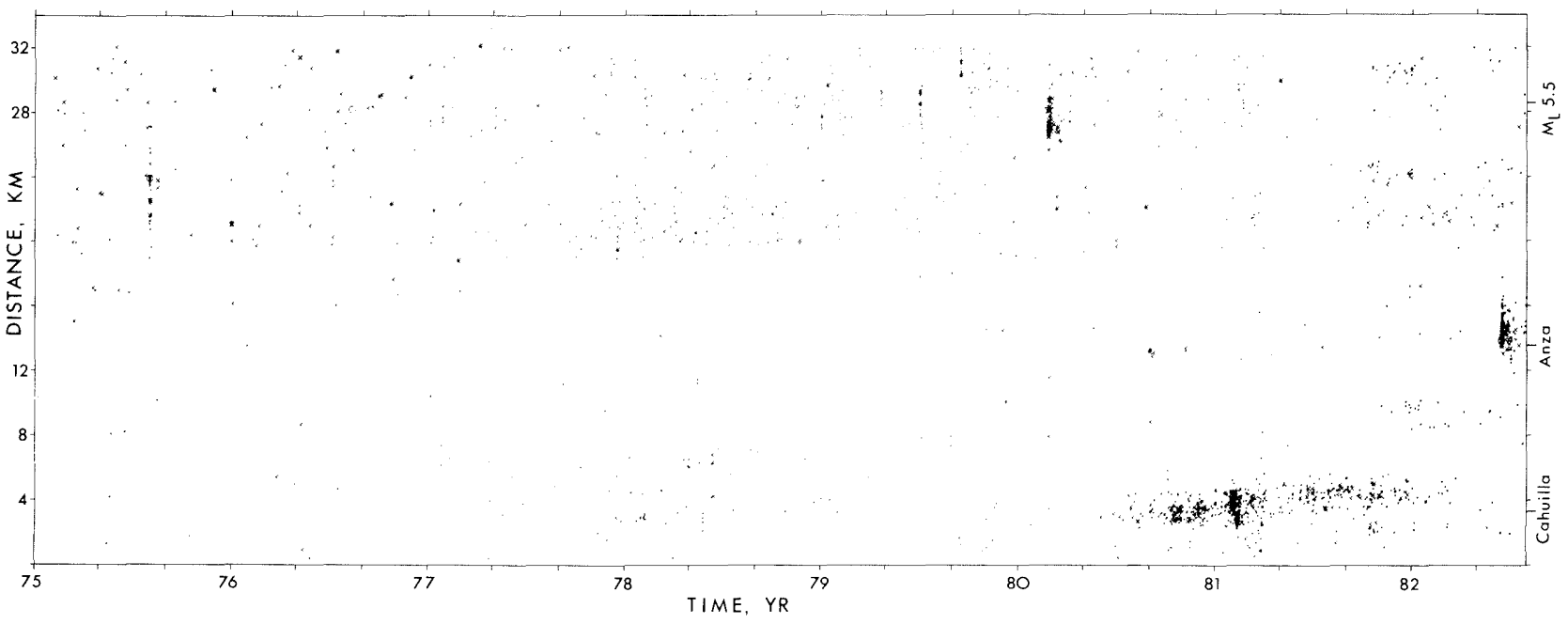

Fig. 15. Earthquake locations with time projected $7 \mathrm{~km}$ or less onto an east-west line extending from the Cahuilla swarm area to the area of the $1980 M_{L} 5.5$ earthquake. 
event, may suggest some sort of mechanical interaction of blocks near the Anza gap. Rupture of the 1980 earthquake loaded the crustal block to the northwest. The Cahuilla swarm began in response to this added strain and continued to release strain, spreading north and slightly east. After the swarm ceased in November 1981, strain was not relieved in this block until 7 months later with the $M_{L} 4.8$ earthquake and aftershocks beneath Anza.

The focal mechanisms of earthquakes beneath Cahuilla Valley have been remarkably consistent at least since June 1978. The mechanism is right slip on a N22 ${ }^{\circ} \mathrm{W}$ striking, $82^{\circ} \mathrm{NE}$ dipping fault plane (Figure 5 , mechanism g) [Sanders et al., 1981]. No surface fault has been mapped near Cahuilla Valley [Sharp, 1967].

Many tremors were felt at Cahuilla in the years preceding the April 1918, $M$ 6.8, San Jacinto-Hemet earthquake (Figure 2). Because these shocks were not reported at other small towns in the area which had been reporting earthquakes, such as Hemet, San Jacinto, and Idyllwild, the earthquakes were probably local and small. The intensities reported by Palmer [1917, 1918, 1919] and Townley and Allen [1939] imply local earthquake magnitudes between $2 \frac{1}{2}$ and $4 \frac{1}{2}$. Beginning $3 \frac{1}{2}$ years before the 1918 earthquake, 16 local tremors were felt, and in the week following the earthquake, three more were reported (Figure 16). No further tremors were mentioned between then and December 1927, the end of the Townley-Allen catalog.

This indication of increased seismicity in the $3 \frac{1}{2}$ years before the 1918 earthquake must be carefully evaluated in light of the method of recording felt earthquakes at Cahuilla during the years 1911-1919. The following important facts were related to us by D. Agnew (personal communication, 1983). The tremer reports from Cahuilla in the TownleyAllen catalog [Townley and Allen, 1939] were collected from the Weather Bureau, which operated a climatological station at Cahuilla from June 1911 to October 1919. This agency, however, did not begin collecting earthquake reports until after the fall of 1914 (a task that was assigned to them by Congress in June of that year). Thus the pre-1918 increase in seismicity may be interpreted as due to observational bias. Also, the regular observer at Cahuilla changed at the end of 1917 , and although several $M 31 / 2$ tremers were reported directly preceding the April 1918 earthquake, reports after the earthquake decline sharply. This may be due to decreased diligence on the part of the new observers or to lessening attention caused by getting used to felt earthquakes (because of all the aftershocks of the nearby 1918 event).

The data revealed by $\mathrm{D}$. Agnew in the previous paragraph seem to throw some ambiguity into the interpretation of the pre- and post-1918 seismicity at Cahuilla. We feel, though, that if the magnitude estimates we give the pre1918 felt earthquakes at Cahuilla are correct, then by comparison with the instrumental record of $M \geqslant 3$ shocks since 1932, the apparent increase in seismicity is indeed real (but may have begun earlier than fall 1914). The reason for the decline of felt earthquakes at Cahuilla after April 1918 is not clear. Information revealed in the following paragraphs seems to indicate that such a low level is normal for this area.

Another significant increase in the earthquake activity

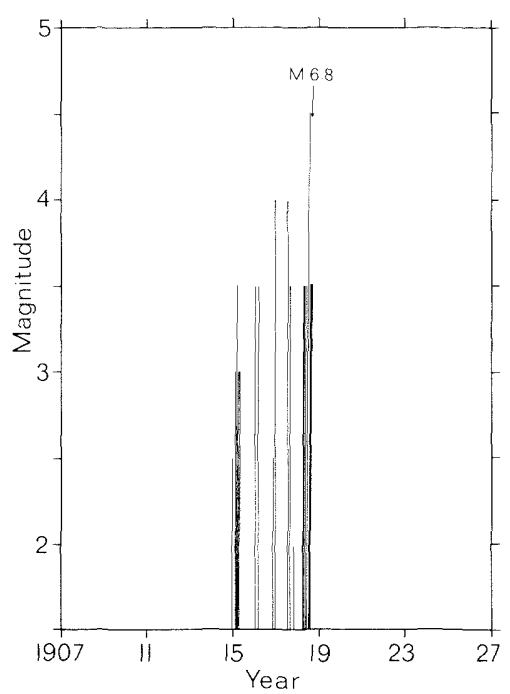

Fig. 16. Plot of approximate earthquake magnitudes with time for the tremors reported felt only at Cahuilla in the years preceding the 1918 San Jacinto earthquake.

near Cahuilla began 11/2 years before the $1937\left(M_{L} 6.0\right)$ earthquake (Figure 2). This swarm of earthquakes, according to the Caltech-USGS earthquake catalog and based on one epicenter determination for the largest $\left(M_{L} 4.6\right)$ earthquake in the swarm, had a location about $12 \mathrm{~km}$ west of Cahuilla. We used the $S-P$ times of the $M_{L} 4.6$ event and several large aftershocks recorded at four southern California seismograph stations ( $110^{\circ}$ azimuthal coverage) to relocate the swarm. Our calculations indicate that these earthquakes were actually located very near Cahuilla in the same area as the 1980-1981 swarm (Figure 17). This is important information since it implies that the Cahuilla area experienced increased seismicity in the years preceding both of the largest historic earthquakes within a $35-\mathrm{km}$ radius of Cahuilla.

The time-space relationship between the increased local earthquake activity at Cahuilla and the 1918 and 1937 earthquakes suggests that the Cahuilla tremers were related to the stress build-up process before the larger events. The ground beneath Cahuilla may be acting as a stress meter signaling the high stresses present before large nearby earthquakes. A similar concept was presented by Kanamori [1972] after studying the relationship between some great Japanese earthquakes and a swarm area on the island of Honshu. Clustering before large and moderate earthquakes in California and elsewhere has also been discussed by Evison [1977] and K.C. McNally (preprint, 1977).

During the recent Cahuilla swarm, as many as 56 $M_{L} \geqslant 2.3$ earthquakes broke at shallow depths beneath Cahuilla. This is similar to the $56 M_{L} \geqslant 2$ earthquakes recorded during the swarm prior to the 1937 event. Activity of this intensity was not reported in the Townley and Allen [1939] catalog for the years following the 1918 earthquake through 1927 (though with possible reporting ambiguity) and is not evident in the Caltech-USGS earthquake catalog from 1937 to 1980 (Figure 17). Thus the present swarm activity is probably the first recurrence of activity beneath Cahuilla since before the 1937 earthquake 


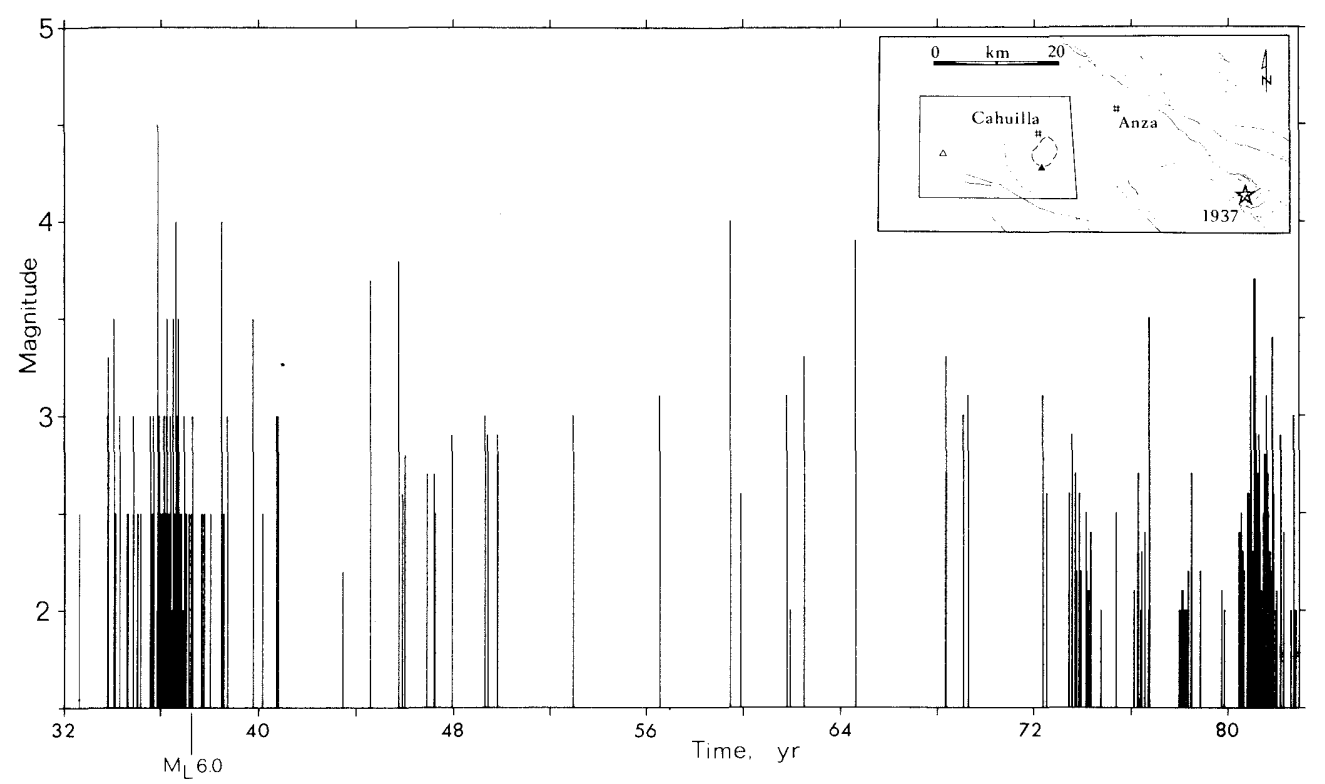

Fig. 17. Plot of earthquake occurrence with time for all earthquakes $M \geqslant 2$ located since 1932 in the Cahuilla swarm area. The index map shows the location of the box within which the small earthquakes occurred. The open triangle indicates the catalog location of the largest event $\left(M_{L} 4.6\right)$ in the 1935 swarm. The solid triangle indicates the revised location based on $S-P$ times. The short dashes outline the area of the recent swarm. The location of the $1937\left(M_{L}\right.$ 6.0) earthquake is shown in space and time on the index map and the stick plot, respectively.

and may be indicating a recent increase of stress in the region.

The location of the Cahuilla swarm relative to the Anza quiescent segment is similar to the locations of the Borrego Mountain earthquake "preshocks" relative to the eventual 1968 rupture zone (Figures 3 and 13); both are located off the respective faults roughly normal to the sections of highest strain accumulation. In addition, the Borrego Mountain "preshocks" are located in nearly the same positions as the off-fault clusters of aftershocks triggered by that earthquake (Figure 13). These aftershock clusters are shallow (Figure $14 b$ ) and coincide with areas of increased shear stress as predicted by analytic dislocation models [Chinnery, 1963; Niewiadomski and Ritsema, 1980; Kostrov and Das, 1982]. Other examples of off-fault aftershocks are consistent with local shear stress increases and normal stress decreases caused by a dislocation in a half space [Das and Scholz, 1981; Kadinsky-Cade and Willemann, 1982; Stein and Lisowski, 1982], suggesting that these dislocation models can be applied to the earth. However, the off-fault stress changes due to the dislocation are so small, only a couple of bars, that they are probably manifested as earthquakes only when they coincide with a relatively weak area of ground or an area of ground already stressed to near its breaking point. Such a weak piece of crust would be sensitive to stress changes occurring both before and after a large earthquake. The nearly coincident positions of the Borrego Mountain off-fault "preshocks" and aftershocks indicate that this part of the crust is relatively weak and is acting as a stress meter sensing the stress changes during the preseismic and postseismic periods. A similar role is suggested for the Cahuilla earthquake swarm area.

Of course, one of the most likely weak crustal zones is a preexisting fault, and preshocks might be expected to occur on one if stress becomes high. However, the detailed locations of the Cahuilla swarm earthquakes and the less well-constrained locations of the Borrego Mountain "preshocks" suggest that stress release is taking place throughout a volume of rock on many discrete small rupture planes rather than on one throughgoing structure. This evidence for stress release on small fracture planes spread throughout a volume is consistent with Kanamori's [1981, Figures 15 and 16] asperity model for precursory swarm seismicity followed by precursory seismic quiescence. The numerous small fractures beneath Cahuilla may have a lower average breaking strength than the surrounding rock or the main fault at Anza and subsequently rupture when the regional strain reaches some limiting value. A swarm occurs when a large number of these small fractures rupture over a relatively short period of time. The number of these fractures is limited, however, and the swarm eventually dies off after most of the fractures have broken. If the remaining fractures in the region have even higher breaking strengths, then relative seismic quiescence ensues until strain accumulates to the point where more ruptures occur.

\section{Regional and Local Strain}

The strain in several areas of southern California has been determined repeatedly by several researchers [Savage and Prescott, 1976; Prescott et al., 1979; Savage et al., 1979, 1981]. Strain rate measurements are important for evaluation of the overall spatial pattern of stress release in the Anza region. The principal strain in the Anza and nearby trilateration networks is north-south compression.

The strain accumulation for the years 1973-1981 in the trilateration networks extending from the Elsinore fault through the Anza area and eastward across the southern San Andreas fault has been presented recently by King and 


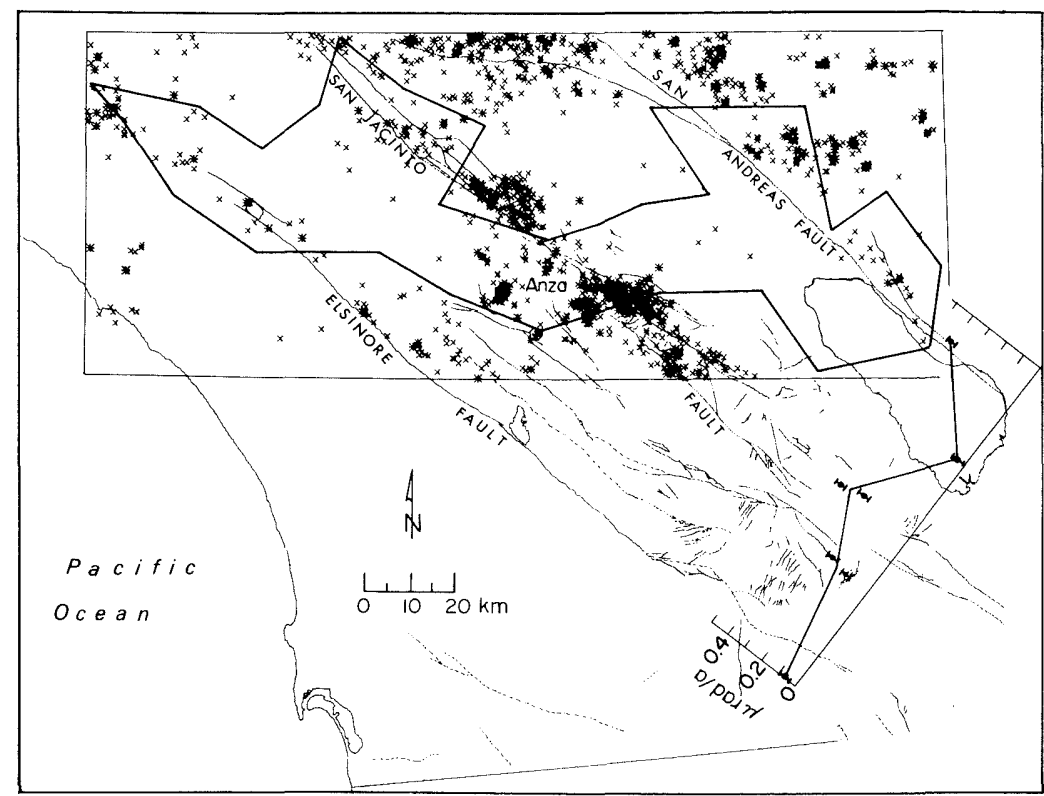

Fig. 18. Map showing the $M \geqslant 2$ earthquakes in the region of the trilateration networks centered on Anza (heavy outline). The corresponding fault parallel shear strain is plotted in the lower right corner [from King and Savage, 1983].

Savage [1983]. Figure 18 shows the outline of the trilateration networks, the seismicity in the area, and the faultparallel shear strain component across the three major faults. The data indicate minimal shear strain accumulation across the Elsinore fault with shear strain increasing progressively eastward in the block between the Elsinore and San Jacinto faults. The strain reaches a maximum of about $0.35 \mu \mathrm{rad} / \mathrm{yr}$ on the San Jacinto fault (about 16 $\mathrm{mm} / \mathrm{yr}$ right slip beneath a $15-\mathrm{km}$-deep locked fault), drops to zero between the San Jacinto and San Andreas faults, and then reaches a maximum of $0.4 \mu \mathrm{rad} / \mathrm{yr}$ across the San Andreas fault. The locations of $M_{L} \geqslant 2$ earthquakes for the same time period mimic the strain data. Few earthquakes are seen on the Elsinore fault with earthquakes increasing in the block between the Elsinore and San Jacinto faults to a maximum on the San Jacinto fault. No earthquakes occur between the San Jacinto and San Andreas faults, and activity increases again near the San Andreas fault.

An important coincidence in the strain and earthquake data is the lack of both shear strain and earthquakes in the block between the San Jacinto and San Andreas faults. The asymmetric pattern of earthquake swarms and clusters about the San Jacinto fault near Anza (Figure 3) may be related to this strain asymmetry.

\section{IMPLICATION OF Focal MeChanisms}

The focal mechanisms for selected earthquakes and groups of earthquakes near Anza are plotted on Figure 5 (see Table 1 for more information on these events). The earthquakes are generally greater than $M_{L} 3$, so the mechanisms are representative of the larger stress release in the area. Besides mechanisms for certain earthquakes mentioned in the text, many mechanisms are shown which are characteristic of the local pattern of stress release.

The focal mechanisms of earthquakes located on the San Jacinto fault (Figure 5, mechanisms a,c,d,h,i,k) indicate right slip on an approximately $\mathrm{N} 53^{\circ} \mathrm{W}$ trending, steeply northeast dipping fault. This is consistent with the trend of the San Jacinto fault, the geologic offset on the fault, and the hypocentral location of small earthquakes.

Of special interest are mechanisms $\mathrm{e}, \mathrm{f}$, and $\mathrm{g}$. Mechanism e is representative of the June 15, 1982, $M_{L} 4.8$ earthquake and large aftershocks, mechanism $f$ is for one $M_{L} 3.6$ earthquake which occurred $12 \mathrm{~km}$ beneath Anza in 1980 , and mechanism $\mathrm{g}$ is representative of most of the earthquakes which occurred in the 1980-1981 Cahuilla swarm. The important feature of these well-constrained focal mechanisms is the orientation of the nodal plane along which right slip occurs. These planes have orientations ( \pm few degrees) of $\mathrm{N} 26^{\circ} \mathrm{W}$ (e), $\mathrm{N} 06^{\circ} \mathrm{W}$ (f), and $\mathrm{N} 22^{\circ} \mathrm{W}(\mathrm{g})$, which are rotated $27^{\circ}-47^{\circ}$ clockwise relative to the local strike of the San Jacinto fault. Two explanations for this seem possible: (1) the stress field in the block southwest of the fault is warped locally and is different from that acting on the fault, or (2) the earthquakes in the block southwest of the fault are breaking on fractures favorably oriented for shear failure under the regional stress field (in which case, the San Jacinto fault is not favorably oriented but still controls the direction of shear failure for the earthquakes rupturing on it).

The former explanation was tested using a twodimensional finite element computer model developed by G. Lyzenga (personal communication, 1981). We hypothesized that if local rotations of the stress field near Anza and Cahuilla are the cause of the rotated mechanisms, then the local stress field is probably warped by stress perturbations caused by the discontinuous Coyote Creek fault and/or the locked fault segment near Anza [Sanders et al., 1981]. The finite element model was formulated in the following manner. The San Jacinto fault northwest and southeast of the Anza gap and the Coyote Creek fault were introduced into the two-dimensional finite element grid as cracks with geometries mimicking the actual mapped surface geometries of these faults. These cracks were assumed to have no shear strength and to slip due to stresses applied 
at the boundaries of the finite element grid. The $20-\mathrm{km}$ long Anza seismic gap was the solid area between the ends of the cracks representing the slipping northwest and southeast San Jacinto fault segments. Far-field stresses (either uniaxial north-south compression or north-south compression and east-west extension) were applied at the grid boundaries, and the resultant principal stresses were computed for each grid element. The results indicate that the local stress axes in the grid elements representing the area near Cahuilla and Anza are not rotated more than a few degrees (G. Lyzenga, personal communication, 1982). This does not support our original hypothesis and suggests that this explanation for the rotated focal mechanisms is probably not correct.

The second explanation appears most valid. The regional principal stress is about $\mathrm{N} 05^{\circ} \mathrm{E}-\mathrm{S} 05^{\circ} \mathrm{W}$ compression [Savage et al., 1981]. Fractures oriented about $\mathrm{N} 25^{\circ} \mathrm{W}$ are most favorably oriented for right-lateral shear failure in this stress system. The small earthquakes occurring beneath Anza and Cahuilla can be considered as rupturing in homogenous material relative to the main fault, and thus these earthquakes rupture more in accordance with the regional stress system and have fault planes oriented $\mathrm{N} 22-27^{\circ} \mathrm{W}$. The San Jacinto fault is not preferentially oriented for shear failure under the present regional stress system, since it is oriented at a $53^{\circ}$ angle to the axis of maximum compression. Numerous earthquakes occur on parts of this fault, however, suggesting that the fault is weaker than the surrounding rock. The largest earthquakes also occur on the San Jacinto fault, so there must be local stronger areas on the fault which are able to store strain over large slip surfaces. The seismological data provide evidence for these localized strength heterogeneities in the Anza gap. These strong spots on the fault near Anza must be relatively strengthened by the compression induced by the high angle between the regional stress axis and the fault surface. They may be responsible for the present quiescent nature of the gap.

\section{Aseismic Fault Slip on the San Jacinto Fault Near Anza}

An alignment array spanning the San Jacinto fault northeast of the town of Anza has been surveyed 13 times since its installation in August 1970. Between the time of the first survey of this array at its installation and the second survey in January 1973, Keller et al. [1978] reported that an apparent $110-\mathrm{mm}$ slip event had occurred over a $300-\mathrm{m}$ wide zone on this part of the fault. Three subsequent surveys to April 1977 showed no significant further change [Keller et al., 1978] nor did eight surveys between April 1978 and December 1982 (J. Louie, personal communication, 1983). Discussions with J. Louie (a Caltech graduate student who is analyzing the southern California slip data) revealed that the Anza alignment array is relatively unstable, since some of the survey targets are located on telephone poles, a tree, and a fence post. He has also noticed that large movements are often measured between the first survey of any alignment array (when it is installed) and the second survey some time later. Apparently, the various survey points need some equilibration time before becoming relatively stable. Keller et al. [1978] acknowledge that the large slip event measured between 1970 and 1973 was not necessarily a valid observation, since many of the survey targets were originally placed in visibly tilted structures which may have tilted further.

Surface fault creep data for the Anza section of the San Jacinto fault, then, is ambiguous. The large slip event between 1970 and 1973 reported by Keller et al. [1978] may not be real. Eleven surveys of the Anza array over the past 10 years (1973-1982), the last eight of which utilized the most stable buried stake targets, reveal no significant slip on the main surface trace of the fault here. In fact, the slip data when averaged between August 1970 and December 1982 actually indicate no net slip during the life of the array (J. Louie, personal communication, 1983). Based on this evidence, we conclude that the San Jacinto fault near Anza for at least the past 10 years has not been relieving significant stress aseismically, at least as measured by surface fault creep.

\section{Conclusions}

The results of this study support the following conclusions:

1. The segment of the San Jacinto fault near Anza, California, has not ruptured in a large earthquake at least since 1892 and can be considered a historic seismic slip gap.

2. Current seismicity defines a $20-\mathrm{km}$-long quiescent fault stretch, the Anza seismic gap, in the center of the historic seismic slip gap.

3. Moderate earthquakes on and near the San Jacinto fault in the seismic gap and their aftershocks indicate that the fault here is seismogenic and highly stressed but locked.

4. No surface fault creep on the San Jacinto fault near Anza has been measured for at least the last 10 years, suggesting that no aseismic release of stress is occurring.

5. The locked nature of the fault may be due to high compressive stress normal to the fault resulting from the local active fault geometries and the orientation of the regional stress field.

6. The Coyote Mountain-Coyote Ridge uplift block appears to be a manifestation of transverse crustal shortening southeast of Anza between the Coyote Creek and San Jacinto faults. The implied large stress drop and limited aftershocks of the 1969 event and the abrupt northwest termination of the 1968 aftershocks are seismological evidence of the high compression normal to the fault planes due to this shortening.

7. The 1980-1981 Cahuilla earthquake swarm relieved stress in an area which was also active before the 1918 San Jacinto-Hemet earthquake and the 1937 Coyote Ridge earthquake. This suggests that the ground beneath Cahuilla may be acting as a stress level monitor signaling the presence of high stresses in the area before large local earthquakes.

8. The length of the quiescent fault segment suggests about $M 6.5$ potential if the entire segment ruptures during one earthquake.

Acknowledgments. We appreciate numerous informative discussions with many individuals, including Doug Given and Bill Stuart of the U.S. Geological Survey, Pasadena; Karen McNally, Jim Pechman, and Ed Corbett 
of the Caltech Seismological Lab; Kerry Sieh and Robert Hill of the Caltech Geology Department; Greg Lyzenga of the Jet Propulsion Laboratory; and Robert Sharp and Tom Hanks of the U.S. Geological Survey, Menlo Park. We also thank Marianne Walck, Kerry Sieh, Robert Sharp, and an anonymous reviewer for their thoughtful editing. The research was supported by USGS contracts 1-14-08-19756 and 64628, 14-08-0001-19266 and 20546. This is contribution 3859, Division of Geological and Planetary Sciences, California Institute of Technology, Pasadena, California, 91125.

\section{REFERENCES}

Allen, C. R., and J. M. Nordquist, Foreshock, main shock, and larger aftershocks of the Borrego Mountain earthquake, U.S. Geol. Surv. Prof. Pap., 787, 16-23, 1972.

Arabasz, W. J., J. N. Brune, and G. R. Engen, Locations of small earthquakes near the trifurcation of the San Jacinto fault southeast of Anza, California, Bull. Seismol. Soc. Am., 60(2), 617-627, 1970.

Brune, J. N., Seismic moment, seismicity, and rate of slip along major fault zones, J. Geophys. Res., 73, 777-784, 1968.

Burford, R. O., Continued slip on the Coyote Creek fault after the Borrego Mountain earthquake, U.S. Geol. Surv. Prof. Pap., 787, 105-111, 1972.

Burford, R. O., and P. W. Harsh, Slip on the San Andreas fault in central California from alinement array surveys, Bull. Seismol. Soc. Am., 70(4), 1233-1261, 1980.

Chinnery, M. A., The stress changes that accompany strike-slip faulting, Bull. Seismol. Soc. Am., 53(5), 921-932, 1963.

Claypole, E. W., The earthquake at San Jacinto, December 25, 1899, Am. Geol., 25, 106-108, 1900.

Corbett, E. J., and K. C. McNally, Changes in stress indicated by "preshocks" to the 1968 Borrego Mountain earthquake (abstract), Eos Trans. AGU, 59(12), 1127, 1978.

Danes, J. V., Das Erdbeben von San Jacinto am 25. Dezember 1899, Mitt. Geogr. Ges. Wein, 6-7, 339-347, 1907.

Das, S., and C. H. Scholz, Off-fault aftershock clusters caused by shear stress increase, Bull. Seismol. Soc. Am., 71(5), 1669-1675, 1981.

Davis, T., and E. Duebendorfer, Surficial structure and geomorphology of the San Andreas fault, western portion of the Big Bend, in, Neotectonics in Southern California, pp. 79-106, Geological Society of America, Boulder, Colo., 1982.

Ebel, J. E., and D. V. Helmberger, $P$-wave complexity and fault asperities, The Borrego Mountain California earthquake of 1968, Bull. Seismol. Soc. Am., 72(2), 413-437, 1982.

Evison, F. F., The precursory earthquake swarm, Phys. Earth Planet. Inter., 15, 19-23, 1977.

Given, D. D., Three-dimensional structure of the trifurcation in the San Jacinto fault zone near Anza, California (abstract), Eos Trans. AGU, 63(45), 1036, 1982.

Gutenberg, B., Earthquakes and structure in southern California, Geol. Soc. Am. Bull., 54, 499-526, 1943.

Hamilton, R. M., Aftershocks of the Borrego Mountain earthquake from April 12 to June 12, 1968, U.S. Geol. Surv. Prof. Pap., 787, 31-54, 1972.

Hanks, T. C., J. A. Hileman, and W. Thatcher, Seismic moments of the larger earthquakes of the southern California region, Geol. Soc. Am. Bull., 86, 1131-1139, 1975.

Hartzell, S., and J. N. Brune, The Horse Canyon earthquake of
August 2, 1975-Two-stage stress-release process in a strike-slip earthquake, Bull. Seismol. Soc. Am., 69(4), 1161-1173, 1979.

Hill, R. I., Geology of Garner Valley and vicinity, in Geology of the San Jacinto Mountains, Field Trip Guideb. 9, edited by A. R. Brown and R. W. Ruff, pp. 90-99, South Coast Geological Society, Irvine, Calif., 1981.

Kadinsky-Cade, K., and R. J. Willemann, Towards understanding aftershock patterns, the basic pattern for strike-slip earthquakes (abstract), Eos trans. $A G U, 63(18), 384,1982$.

Kanamori, H., Relation between tectonic stress, great earthquakes, and earthquake swarms, Tectonophysics, 14, 1-12, 1972.

Kanamori, H., Seismicity and earthquake prediction examples in southern California, in Proceedings of the Earthquake Prediction Research Symposium, Seismological Society of Japan, Tokyo, 1980.

Kanamori, $H$., The nature of seismicity patterns before large earthquakes, in Earthquake Prediction, An International Review, Maurice Ewing Ser. vol. 4, edited by D. W. Simpson and P. G. Richards, pp. 1-19, AGU, Washington, D. C., 1981.

Kanamori, H., and P. C. Jennings, Determination of local magnitude, $M_{L}$, from strong-motion accelerograms, Bull. Seismol. Soc. Am., 68(2), 471-485, 1978.

Keller, R. P., C. R. Allen, R. Gilman, N. R. Goulty, and J. A. Hileman, Monitoring slip along major faults in southern California, Bull. Seismol. Soc. Am., 68(4), 1187-1190, 1978.

King, N. E., and J. C. Savage, Strain rate profile across the Elsinore, San Jacinto, and San Andreas faults near Palm Springs, California, 1973-1981, Geophys. Res. Lett., 10(1), 55-57, 1983.

Kostrov, B. V., and S. Das, Idealized models of fault behavior prior to dynamic rupture, Bull. Seismol. Soc. Am., 72(3), 679-703, 1982.

Laughlin, H., R. Arnold, and W. S. W. Kew, Southern California earthquake of July 22, 1923, Bull. Seismol. Soc. Am., 13(3), 105-106, 1923.

Lisowski, M., and W. H. Prescott, Short-range distance measurements along the San Andreas fault system in central California, 1975 to 1979, Bull. Seismol. Soc. Am., 71(5), 1607-1624, 1981.

McEvilly, T. V., W. H. Bakun, and K. B. Casady, The Parkfield, California, earthquakes of 1966, Bull. Seismol. Soc. Am., 57(6), 1221-1244, 1967.

Meissner, R., and J. Strehlau, Limits of stresses in continental crusts and their relation to the depth-frequency distribution of shallow earthquakes, Tectonics, I(1), 73-89, 1982.

Niewiadomski, J., and A. R. Ritsema, The stress field induced by cracks and the occurrence of earthquakes, Proc. K. Ned. Akad. Wet. Ser. B, 83(4), 361-377, 1980.

Palmer, A. H., California earthquakes during 1916, Bull. Seismol. Soc. Am., 7(1), 1-17, 1917.

Palmer, A. H., California earthquakes during 1917, Bull. Seismol. Soc. Am., 8(1), 1-12, 1918.

Palmer, A. H., California earthquakes during 1918, Bull. Seismol. Soc. Am., 9(1), 1-7, 1919.

Pechmann, J. C., The relationship of small earthquakes to strain accumulation along major faults in southern California, Ph.D. thesis, Calif. Inst. of Technol., Pasadena, 1983.

Prescott, W. H., J. C. Savage, and W. T. Kinoshita, Strain accumulation rates in the western United States between 1970 and 1978, J. Geophys. Res., 84(B10), 5423-5435, 1979.

Rasmussen, G. S., Nature of surface rupture and recurrence interval, Casa Loma fault, in Geology of the San Jacinto Mountains, Field Trip Guideb. 9, edited by A. R. Brown and R. W. Ruff, pp. 48-54, South Coast Geological Society, Irvine, Calif., 1981. 
Richter, C. F., Elementary Seismology, 768 pp., W. H. Freeman, San Francisco, Calif., 1958.

Rogers, T. H., Geologic map of California, San Bernardino 1:250,000 sheet, Calif. Div. of Mines and Geol., Sacramento, 1967.

Rolfe, F., and A. M. Strong, The earthquake of April 21, 1918 in the San Jacinto mountains, Bull. Seismol. Soc. Am., 8(2-3), 63$67,1918$.

Sanders, C. O., and H. Kanamori, Seismicity patterns near the Anza seismic gap, paper presented at the AGU Chapman Conference on Fault Behavior and the Earthquake Generation Process, Snowbird, Utah, 1982.

Sanders, C., K. McNally, and H. Kanamori, The state of stress near the Anza Seismic Gap, San Jacinto fault zone, southern California, in Geology of the San Jacinto Mountains, Field Trip Guideb. 9, edited by A. R. Brown and R. W. Ruff, pp. 61-67, South Coast Geological Society, Irvine, Calif., 1981.

Savage, J. C., and W. H. Prescott, Strain accumulation on the San Jacinto fault near Riverside, California, Bull. Seismol. Soc. Am., 66(5), 1749-1754, 1976.

Savage, J. C., W. H. Prescott, M. Lisowski, and N. King, Deformation across the Salton Trough, California, 1973-1977, J. Geophys. Res., 84(B6), 3069-3079, 1979.

Savage, J. C., W. H. Prescott, M. Lisowski, and N. King, Strain accumulation in southern California, 1973-1980, J. Geophys. Res., 86(B8), 6991-7001, 1981.

Sharp, R. V., San Jacinto fault zone in the Peninsular Ranges of southern California, Geol. Soc. Am. Bull., 78,705-730, 1967.

Sharp, R. V., Map of recently active breaks along the San Jacinto fault zone between the San Bernardino area and Borrego Valley, California, U.S. Geol. Surv. Misc. Geol. Invest. Map, I-675, 1972.

Sharp, R. V., En echelon fault patterns of the San Jacinto fault zone, in San Andreas Fault in Southern California, edited by J. C. Crowell, Spec. Rep. Calif. Div. Mines Geol., 118, 147-154, 1975.

Sharp, R. V., Variable rates of Late Quaternary strike-slip on the San Jacinto fault zone, southern California, J. Geophys. Res., 86(B3), 1754-1762, 1981.

Sibson, R. H., Fault zone models, heat flow, and the depth distribution of earthquakes in the continental crust of the United
States, Bull. Seismol. Soc. Am., 72(1), 151-163, 1982.

Sieh, K. E., and R. H. Jahns, Holocene activity of the San Andreas fault at Wallace Creek, California, Geol. Soc. Am. Bull., in press, 1984.

Slemmons, D. B., Faults and earthquake magnitude, Misc. Pap. $S$ 73-I, 166 pp., Chief of Eng., U.S. Army, Washington, D. C., 1977.

Stein, R. S., and M. Lisowski, Post-earthquake stress changes control off-fault aftershocks and ground rupture for the $1979 M=5.6$ Homestead Valley, California earthquake, paper presented at the AGU Chapman Conference on Fault Behavior and the Earthquake Generation Process, Snowbird, Utah, 1982.

Thatcher, W., and R. M. Hamilton, Aftershocks and source characteristics of the 1969 Coyote Mountain earthquake, San Jacinto fault zone, California, Bull. Seismol. Soc. Am., 63(3), 647-661, 1973.

Thatcher, W., J. A. Hileman, and T. C. Hanks, Seismic slip distribution along the San Jacinto fault zone, southern California and its implications, Geol. Soc. Am. Bull., 86, 1140-1146, 1975.

Toppozada, T. R., and C. R. Parke, Areas damaged by California earthquakes 1900-1949, Open File Rep. 82-17 SAC, Calif. Div. Mines and Geol., Sacramento, 1982.

Toppozada, T. R., C. B. Real, and D. L. Parke, Preparation of isoseismal maps and summaries of reported effects for pre- 1900 California earthquakes, Open File Rep. 81-11 SAC, Calif. Div. Mines and Geol., Sacramento, 1981.

Townley, S. D., The San Jacinto earthquake of April 21, 1918, Bull. Seismol. Soc. Am., 8(2-3), 44-62, 1918.

Townley, S. D., and M. W. Allen, Earthquakes in California, 1769 to 1928, Bull. Seismol. Soc. Am., 29, 1-258, 1939.

Weldon, R. J., and K. E. Sieh, Offset rate and possible timing of recent earthquakes on the San Andreas fault in Cajon Pass, California (abstract), Eos trans. $A G U, 62(45), 1048,1981$.

Wood, H. O., The Terwilliger Valley earthquake of March 25, 1937, Bull. Seismol. Soc. Am., 27, 305-312, 1937.

C. O. Sanders and H. Kanamori, Seismological Laboratory 252-21, California Institute of Technology, Pasadena, CA 91125.

(Received May 10, 1983; revised December 9, 1983; accepted January 25,1984 .) 